\title{
RUUT VEENHOVEN
}

\author{
IS HAPPINESS A TRAIT? \\ Tests of the Theory that a Better Society does not \\ Make People any Happier ${ }^{1,2,3}$
}

(Accepted 16 May, 1993)

\begin{abstract}
One of the ideological foundations of the modern welfare states is the belief that people can be made happier by providing them with better living conditions. This belief is challenged by the theory that happiness is a fixed 'trait', rather than a variable 'state'. This theory figures both at the individual level and at the societal level. The individual level variant depicts happiness as an aspect of personal character; rooted in inborn temperament or acquired disposition. The societal variant sees happiness as a matter of national character; embedded in shared values and beliefs. Both variants imply that a better society makes no happier people.

Happiness can be regarded as a trait if it meets three criteria: (1) temporal stability, (2) cross-situational consistency, and (3) inner causation. This paper checks whether that is, indeed, the case.

The theory that happiness is a personal-character-trait is tested in a (meta) analysis of longitudinal studies. The results are: (1) Happiness is quite stable on the short term, but not in the long run, neither relatively nor absoloutely. (2) Happiness is not insensitive to fortune or adversity. (3) Happiness is not entirely built-in: its genetic basis is at best modest and psychological factors explain only part of its variance.

The theory that happiness is a national-character-trait is tested in an analysis of differences in average happiness between nations. The results point in the same direction: (1) Though generally fairly stable over the last decades, nation-happiness has changed profoundly in some cases, both absolutely and relatively. (2) Average happiness in nations is clearly not independant of living conditions. The better the conditions in a country, the happier its citizens. (3) The differences cannot be explained by a collective outlook on life.

It is concluded that happiness is no immutable trait. There is thus still sense in striving for greater happiness for a greater number.
\end{abstract}




\section{INTRODUCTION}

\section{The Pursuit of Happiness}

Happiness is a main goal in present day Western society. Individually, people try to shape their lives in such ways that they can enjoy them. Politically, there is massive support for policies that aim at greater happiness for everybody. It is widely believed that we can get happier than we are. There is also consensus that we should not acquiesce in current unhappiness.

The belief that we can get happier is rooted in the Humanistic view of man. Rather than a helpless being expelled from Paradise, man is seen as autonomous, and able to improve his condition by the use of reason. This view was at the core of the 19th century Utopian movement and is still at the ideological basis of the 20th century Welfare States. Planned social reform, guided by scientific research, is expected to result in a better society with happier citizens.

The conviction that we should try to improve happiness is rooted in Enlighted thought as well. The notion that happiness is to be preferred above unhappiness figured already in ancient Greek moral philosophy. In the 19th century it crystallized into the Utilitarian doctrine that the moral value of all action depends on the degree to which it contributes to the 'greatest happiness for the greatest number'. Though few accept happiness as the only and ultimate goal in life, it is generally agreed that happiness is worth pursuing. Happiness ranks high in public opinion surveys on value priorities. See a.o. Harding (1985: 231.)

This ideology is not unchallenged however. It is argued that happiness is not the most valuable goal and it is claimed that we cannot get happier even if we would want to.

The objection that happiness is not worth pursuing rests partly in religious doctrines that glorify suffering. Such doctrines figure in Calvinist moral philosophy and in some variants of Hinduism. Objections come also from advocates of other endvalues who are eager to depreciate the competitor. Many Marxists for instance reject happiness as something 'false', equality being the only 'true' value they accept. Such moral objections find support in theories about adverse effects of happiness. Happiness is said to make people politically uncritical, socially unre- 
sponsive and morally decadent. Mild unhappiness would be preferable in the long run. Elsewhere I have examined these claims empirically and found most of them untrue. See Veenhoven $(1988,1989$.

The objection that we cannot raise happiness, even if we wanted to, rests on two lines of thought. The first is that we are unable to change society according to plan; this is the theme of limits to social engineering. The second denunciation is that even successful improvement of society would help little. A better society would not make people any happier. This latter objection draws on two theories: One theory holds that happiness is 'relative'. Any improvement in living conditions would soon result in a rise in standards of comparison and would therefore leave us as (un)happy as before. The other theory is that happiness is a fixed 'trait' rather than a variable 'state'. Improvements of external living conditions would therefore not result in greater happiness, the evaluation of life being largely determined by an internal disposition to enjoy it. Elsewhere I have tested the theory that happiness is relative (Veenhoven, 1991). That theory was largely refuted. This paper considers the claim that happiness is a fixed trait. This latter theory will appear to lose considerable ground as well.

\section{The Idea of Fixed Happiness}

The notion that happiness is essentially unalterable figures in psychological thinking as well as in sociological thought.

Psychologists who adhere to this view think of happiness or unhappiness as a stable disposition towards life rather that as the variable outcome of an ongoing evaluation of it. Some even regard happiness as a 'personality' trait: that is a tendency to react (judge life) similarly across different situations. Chronic states, as manifested in some forms of pathological unhappiness (depression, ahedonia), are believed to be the rule.

Sociologists in this tradition see the happiness of individuals as a reffection of collective 'national character'. The outlook on life implied in common values and beliefs is seen to pervade individual perceptions and evaluations. As collective outlook is largely an invariant matter, individual judgements geared by it are seen to be rather static as well. 


\section{Personal Character}

The idea of a 'happy personality' has several variations. One is that people are born as either happy or unhappy. In this view happiness is a temperamental disposition, possibly based in the neurophysiological structure of pleasure centers in the brain. Some people would be apt to feel cheerfull and hence be positive about their life, even in difficult conditions, whereas others are prone to depression and hence judge their lives negatively, even in favourable situations. See a.o. Tellegen (1988).

Another variation is that happiness is an acquired disposition. Some people would develop a positive attitude towards life, whereas others would become sour. In this vein Lieberman (1970: 74) wrote: “. . at some point in life, before even the age of 18 , an individual becomes geared to a certain stable level of satisfaction, which - within a rather broad range of environmental circumstances - he maintains throughout life".

Whatever the variant, the idea of happiness as a personality trait implies that people tend to remain as happy or unhappy as they are, and that improvement or detoriation in their living conditions does not make them more or less happy. An explicit account of this implication can be found with Costa et al. (1987: 305), who write: “... happiness is ultimately also independant of health, youth, power and other life circumstances...".

\section{National Character}

The idea that there are happy and unhappy nations is part of common sense knowledge. For example: the Italians are seen as easygoing and light-hearted, whereas the Swedes are attributed a gloomy outlook on life. Comparision of average scores on survey questions about happiness show striking differences between nations, though typically not the ones predicted (see table 3 ).

Sociologists who have considered these differences also refer to cultural variation in outlook. Inkeles (1990/91: 93) for instance attributes the difference in happiness between nations to "national creed". "Given the tendency to report oneself as happy or unhappy seems to be a relatively stable characteristic of given national populations, in short a statistically reliable measure of the feeling state of the nation, 
would seem to justify describing it as truly a national character trait". Likewise Inglehart (1990: 30) writes that cross-national differences in happiness "reflect cognitive cultural norms, rather than individual grief and joy". He sees these norms as rooted in "profound differences in outlook" between nations.

Two issues tend to be confused in discussions on this matter: 'cultural bias' in measurement of happiness and 'culturally induced difference' in happiness itself. The attention has been focused very much on the issue of measurement bias (Ostroot and Snyder, 1985, Veenhoven, 1986, Ouweneel and Veenhoven, 1989). Yet most relevant in the discussion at issue here is the presumed effect of cultures on the evaluation of life as such.

\section{Approach}

The aim of this paper is to explore the tenability of these claims empirically. Is happiness really that unalterable a matter that it is not worth trying to reach out for more? To answer this question I will take stock of the available research findings and check whether happiness appears to be static or not.

First I will check the claim that happiness is in itself a rather invariant 'personality trait'. I will consider the available longitudinal studies on happiness to assess its stability over time, as well as its sensitivity to fortune and adversity. I will also inspect whether the evaluation of life is largely determined by 'inner' psychological characteristics rather than by 'external' living conditions. That analysis will be at the individual level.

Next I will consider the hypothesis that average happiness in nations reflects a collective 'idea fixe' rather than the actual quality of life in the country. For that purpurse I will consider the stability of average happiness in nations: how stable is it over time, how dependant on living conditions in the nations and how much rooted in shared values and beliefs. That analysis will be at the societal level. 


\section{Concept of Happiness}

The answer to these questions depends on the precise concept of happiness used. Some things called happiness are more static than others. 'Frustration-tolerance' is for instance likely to be more stable than 'elated mood'. The current confusion about variability of happiness is in fact largely due to sloppy conceptualisation of the matter.

The concept of happiness used here is in line with the Utilitarian conception of happiness as the 'sum of pleasures and pains'. The focus is on the 'subjective' appreciation of life and not on any 'objective' qualities of the individual himself or his living conditions. Happiness is defined as the degree to which an individual evaluates the overall quality of his/her life-as-a-whole positively. This definition is delineated in more detail in Veenhoven (1984: ch 2). Within this concept two components of happiness are distinguished. The first component is hedonic level of affect, which is the degree to which pleasant affective experiences outbalance unpleasant ones generally. The second component is called contentment and concerns the degree to which the individual perceives his wants to have been met. These components represent respectively 'affective' and 'cognitive' appraisals of life and are seen to figure as sub-totals in the overall evaluation of life, called overall happiness.

\section{Measures of Happiness}

Happiness as defined here can be measured by means of questioning. Various claims to the contrary have been disproven empirically. (Research reviewed in Veenhoven, 1984: ch 3). Though measurable in principle, not all the questions and scales that are used measure this kind of happiness validly. Elsewhere I have reviewed current indicators and distinguished between acceptable and unacceptable ones (Veenhoven, 1984: ch 4). This paper considers only data based on indicators that were deemed acceptable. As a consequence several well known studies on this matter are left out. The studies used here were located by means of the World Database of Happiness (Veenhoven, 1992).

\section{Concept of Trait}

The term 'trait' is used in contrast to 'state'. A trait is seen as a durable characteristic of a person or society, that is in some way 'built-in'. A 
trait is a 'chronic' phenomenon. On the other hand a state is thought of as something essentially variable, that is continually (re-)produced. Traits are typically seen as causes, states as results.

Several criteria have been suggested to mark the difference more sharply. See Chaplin et al. (1988). Three of these are relevant for the problem at hand here, (1) temporal stability, (2) cross-situational consistency, and (3) internal (rather than external) causation. These three criteria will be used in the following tests of the theory that happiness is a trait.

\section{IS HAPPINESS A PERSONAL TRAIT?}

The question whether happiness can be characterized as a stable personal 'trait' rather than a variable 'state' is not new: trait-state discussions have raged in many fields of psychology. In the field of subjective well-being the issue was already under debate in the thirties (Young, 1937). Recent contributions to this discussion have been made by Aron and Aron (1987), Costa $(1984,1987,1988)$, Chamberlain and Zika (1992), Kozma (1990), McNeal et al. (1986), Mohr (1986), Mortimer and Lorence (1981), Mussen (1980, 1982), Harley and Lavery (1991), Ormel (1980), Palmore (1977), Stones et al. (1986, 1989, 1991) Tellegen et al. (1988) and Yardley and Rice (1991). Most of these authors stress the trait-character of subjective well-being, in particular Stones and Kozma who conclude that happiness can be raised only by psycho-therapy (1989: 534). Conclusions are typically based on rather fragmentary data, short follow-ups and dubious indicators of happiness.

I will now consider the matter in the light of all the data that is currently available. These data allow a test of three hypotheses involved in the theory that hapiness is a personal trait. These hypotheses are implied in the definition of trait above. The first hypothesis is that happiness is temporally stable (par. 2.1), the second that it is transsituationally consistent (par. 2.2) and the third that it is internally caused (par. 2.3). 


\subsection{Temporal stability: Do the happy remain happy?}

The notion of a personal 'trait' involves different assumptions, which tend to be confused in this discussion. One assumption is that some people are characteristically more happy than others. Even if living conditions were identical for everybody, there would be happy and unhappy people. When these people go through similar ups and downs in life, the difference remains; their happiness rises and drops in the same degree, but change starts at a different level. This view is pictured in figure 1a. Let's call this the relative stability of happiness.

The other assumption is that the appreciation of life is so much a dispositional matter that it hardly follows ups and downs at all. In this view happiness remains essentially at the same level, irrespective of the actual quality of life and changes for the better or worse. This more extreme view is depicted in figure $1 \mathrm{~b}$. I will refer to it as absolute stability.

This latter theory is at issue here. Theory $1 \mathrm{~b}$ denies that improvement of living conditions adds to the subjective appreciation of life and thus predicts that a better society makes no happier citizens. Theory la does not. It only renounces the possibility that everybody can be made equally happy, social progress prolonging the difference between happy and unhappy at a higher average level.

\section{Relative Stability}

Relative temporal stability is mostly assessed by means of follow-up studies and expressed in overtime-correlations. An overtime-correlation of +0.90 means that the rankorder of happiness in a population has almost remained the same during the period studied. Several investigations have reported high overtime-correlations of happiness. These results are often cited.

In order to obtain a more complete view I gathered all studies that have ever assessed overtime-correlations of happiness. I found some hundred studies, of which 26 appeared to have used acceptable indicators of happiness. Together these studies yield 65 overtime-correlations: 30 on overall happiness, 25 on hedonic level and 6 on contentment. The time span of these studies varies from one month to forty years. The 
(1a): Happiness varies with ups and downs in life, but interpersonal differences tend to remain. (1b): Happiness remains essentially the same through time, both absolutely and relatively.
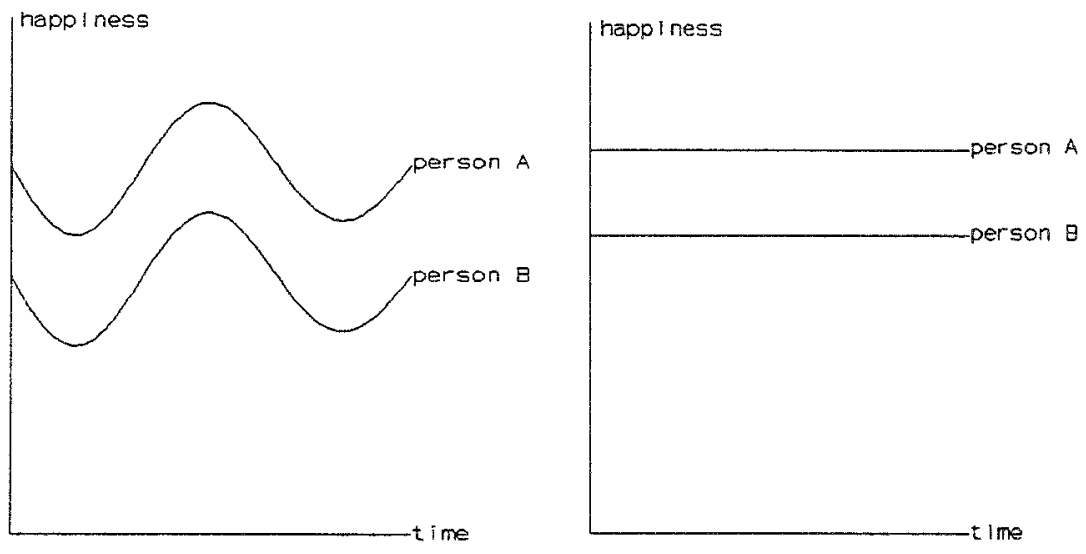

Fig. 1. Variants of the theory that happiness is a personal trait.

correlations are presented in exihibit 2 in a time diagram. The data are presented in more detail in appendix 1.

\section{Stable on the Short Term, but not on the Long Run}

Trait-theory is confirmed by the fact that overtime-correlations are almost all positive. However most of the correlations cannot be defined as 'high'. The range of the correlations is from -0.10 to +0.70 , the average around +0.35 .

It appears that the stability of happiness is a short-term matter. The highest correlations concern mainly time lags of several months; overtime correlations are around +0.60 . Over the years the correlations drop considerably. After five years overtime-correlation is almost halved and varies around +0.30 . Over periods of ten to fifteen years the correlation shrinks back to about +0.15 . Extrapolation of this trend predicts complete disappearance of all overtime-correlation after twenty years. However, the only study that covered a longer period observed a slightly 
higher overtime-correlation. In Mussen's forty year follow-up the average correlation is +0.23 . Possibly this is due to the measurement method used in that study. It assessed happiness by means of interviewer ratings rather than by means of self-reports. The interviewer ratings may have been coloured by simultaneous observation of some stable personality traits.

Even if Mussen's observation is correct, it indicates that happiness in young adulthood explains only some $10 \%$ of happiness in late adulthood.

The true stability of happiness is probably somewhat higher than the correlations suggest. The size of overtime-correlations depends also on the accuracy of measurement: many errors depress the correlation. True stability can be estimated by 'disattenuation' of overtime-correlations: by dividing them by the reliability coefficient. The reliability of single direct questions on happiness as assessed by repeating the question in an interview or by retests after some days is typically about +0.70 . That means that the true stability of happiness is probably some $40 \%$ higher: about +0.77 after one year, about +0.50 after five years, and about +0.40 after ten years.

The decline of the overtime-correlations follows a curvilinear pattern. Stability drops sharply in the first few years, but stabilizes at a low level in the longer run. The asymptote is probably about +0.20 . This suggests that there is some minor 'hard core'. However it is not at all sure that this hard core represents the hypothesized 'personality trait'. It could just as well be constancy in living conditions or constancy in traits other than happiness. We will deal further with this possibility in paragraph 2.3.

Overtime-correlations of measures of 'hedonic level' (largely Bradburn's Affect Balance Scale) are typically lower than those of the indicators of 'overall happiness' and 'contentment'. This is consistent with the view of happiness as an acquired attitude to which people tend to stick to cognitively, unless major changes lead to a reorientation. The relatively low stability of hedonic level of affect does not fit the theory that tendency to feel cheerful or not is largely inborn. This claim will be considered in more detail in 2.3 as well. 
(2a): Predicted pattern: happiness remains stable over the years.

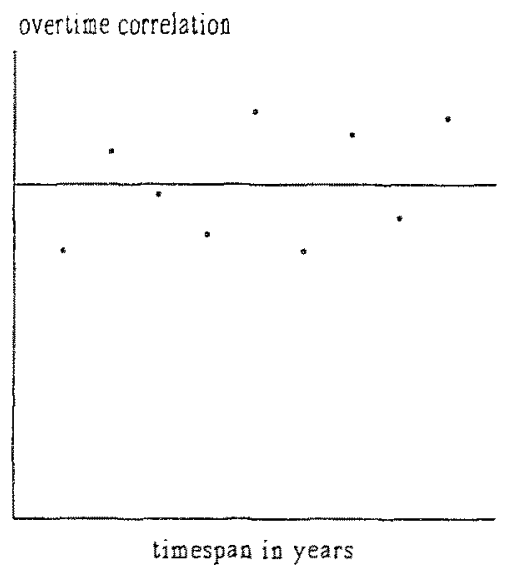

(2b): Observed pattern: happiness is not very stable in the long run.

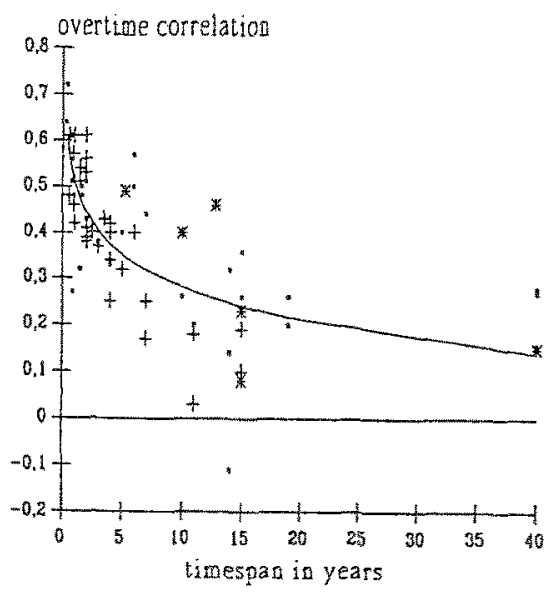

Fig. 2. Overtime-correlations of happiness observed in 26 longitudinal studies. Data: Appendix 1: $+=$ overall happiness $\cdot=$ affect level $*=$ contentment.

\section{Lower Stability through Serious Lifechange}

If happiness is a trait, overtime-correlations must remain at the same level, even in periods of profound lifechange. If however happiness is essentially a judgement that is continually re-assessed, we can expect a drop in overtime-correlations in periods of transition. There are three reasons to expect this. First, transitions may involve a change in quality of life and hence invite a change in the evaluation of it. Secondly, new situations press towards a reorientation on life anyway. Thirdly, re-orientation typically involves some time of changing tentative judgements before the individual decides on a more definitive evaluation of this life. During this period the temporal stability of happiness is likely to be low as well.

Several studies have assessed overtime-correlations among subjects who went through some transition. Mostly the transitions considered are not very dramatic: leaving school, entering marriage, taking a new job, 
moving to an other house, etc. Overtime-correlations appear slightly lower among such transitions, but not much. (Data not shown). However, overtime-correlations do seem to be lower at times when really dramatic events occur. Waltz (1986: 77) observed a lower overtimecorrelation among cardiac patients in the first half year after their first heart attack, than in the second half year. T1-T2 correlation was about +0.40 ; which is relatively low on a 6 month interval. T2-T3 correlation was about +0.60 which is around the usual level.

\section{Absolute Stability}

Overtime-correlations indicate the degree to which differences in happiness between subjects remain similar over time (relative stability), but do not inform about stability in the level of happiness (absolute stability). In other words: high overtime-correlation does not mean absence of change.

This matter is nicely illustrated in the case of renal patients who received a donor-kidney. The happiness of these patients increased dramatically after the transplant. When still on the waiting list only $31 \%$ saw themselves as happy, but one year after the transplant no less than $79 \%$ did so! This temporal upsurge of happiness is known as the 'Golden period'. Still the overtime-correlation in this period is quite sizable: $r=+0.46 \mathrm{p}<0.001$ (Simmons et al., 1977: 61-62).

' In a parallel study of kidney donors these investigators show in more detail how happiness changes after transplantion. Only $32 \%$ appear to have remained equally happy one year after the donation: $24 \%$ became less happy and $44 \%$ became more happy. Those initially least happy were most likely to have experienced a decrease in life-satisfaction, while those initially most happy had profited most (pp. 180-192). Thus the relative differences have been largely maintained, whereas the absolute levels of happiness have changed profoundly.

\section{Happiness is Quite Variable}

The easiest way to assess absolute stability of happiness is to ask people how happy they have been over the years. A common device for that purpose is the 'Life-Satisfaction Chart' (Kuhlen, 1948) on which 
respondents characterize their retrospective happiness by a line in a graph. If happiness is a trait, people must typically draw horizontal lines: if it is rather a state-like matter, deflections will be the rule. The latter pattern is by far the most common. Most people remember distinct differences in happiness. (Data not shown).

It is of course possible that reminiscences about happiness in earlier phases of life are inaccurate and that differences in earlier happiness tend to be over-estimated. Therefore we must also consider follow-up studies of present happiness. A good study of that kind was performed by Landua (1992). Landua analysed the yearly reponses on a 11 point lifesatisfaction scale over a four-year period. He focused on 'substantial' changes; that is changes between four main categories (score 0-4, 5-6, 7-8 and 9-10). Only $10 \%$ of his respondents appeared to have stayed in the same satisfaction category for all four years; $90 \%$ had moved to another category. Landua observed quite radical changes: of the initially very unhappy movers (score $0-4$ ) no less than $18 \%$ came to see themselves as very happy (score 9-10) in this four-year period. Similarly Heady and Wearing (1992: 126) found that about one third of their subjects in an 8 year panel study changed more then one standard deviation in both overall happiness and hedonic level.

\section{Unhappiness less Constant than Happiness}

If happiness is a fixed trait, dissatisfaction with life must be equally invariant as satisfaction. If however happiness is rather a judgement that is periodically reviewed, we can imagine that dissatisfaction is less of a lasting matter. We can expect so, because the discomfort of unhappiness involves a pressure to change; either to improve livingconditions or to revise ones judgement of life. On the other hand the happy are likely to maintain their judgement of life unless serious adversity urges a re-evaluation.

This implication can also be tested with the results of the 4-year follow up study mentioned above (Landua 1992); happiness must then be similar among 'stayers' and 'movers'. However, Landua observed that the unhappy make up a larger proportion of the movers than of the stayers ( $27 \%$ vs $12 \%)$. 
Source of Stability can be Conditions for Happiness Rather than Happiness-as-such

Though less than expected, the constancy of happiness over time is still note-worthy. Does that mean that happiness is at least partly a personal trait? Not necessarily so. The statistical stability can also be the result of other things than an inner disposition to enjoy life.

Firstly, the correlations can be due to the stability of other personal characteristics other than happiness: f.e. to good health, a nice character and ability to deal with the problems of life. Such traits other than happiness can obviously add to the chance that things go well in life and hence that satisfaction with life tends to remain high. Happiness appears then as a stable trait, but is in fact an essentially variable state reproduced over and again.

Secondly, the overtime-correlation can be due to stability in living conditions. People who have a high income, a nice spouse and good connections mostly maintain these advantages over their lifetime. Sociologists have shown that there is much continuity in social inequalities.

\section{Overtime-Correlation Disappears after Controls}

In order to isolate these effects empirically, we must remove the influence of stable pre-conditions for happiness from the overtimecorrelations. I know only of one study that involved such an analysis. Chiriboga (1984: 474) considered the stability of happiness over 11 years in a sample of people in transition. He controlled baseline personality and social status. He found hardly any overtime-correlation: $B=+0.02$ among males and -0.18 among females. Not baselinehappiness appeared to predict happiness 11 years later, but baselinepersonality; in particular earlier mental health and self-criticism predicted later happiness.

\subsection{Situational Consistency: Are People Equally Happy in Fortune and Adversity?}

If happiness is a trait-like disposition rather than a state-like evaluation of life, happiness must remain largely the same in different situations. 
People living in good conditions can then be expected to be equally happy as people in bad conditions. Change for the better or worse will not render them any happier or unhappier. Some authors claim that this is exactly what empirical research has shown: a remarkable lack of correspondence between 'objective' living conditions and the 'subjective' appreciation of life. See Brickman et al. (1978: 925), Easterlin (1974) and Inglehart and Rabier (1985: 30).

\section{Perceived Effects}

A first test of this hypothesis is checking whether it fits common lifeexperience. This can be done by asking people whether major lifeevents in the past did affect their happiness at that time. De Frain and Emst (1978: 988) asked parents about their adjustment to sudden death of their infant some years ago. These parents typically report a drastic drop in their personal happiness at the death of their infant, followed by a gradual recovery to the original level in 2 to 3 years. Likewise, studies with the above mentioned 'Life-Satisfaction Chart' show that people link up and downs in retrospective happiness with specific positive and negative times in their life (McKinley Runyan, 1979). Reminiscences may be inaccurate however, and biased by the evaluation of events. Therefore we must also consider situational correlates of present happiness.

\section{Actual Effects}

Comparisons of present happiness across situations show some striking non-differences. There is for instance little difference in happiness between rich and poor; at least in affluent welfare states. In present day Western nations happiness is neither related to age, sex nor education. Yet it is an exaggeration to say that happiness does not relate to any circumstances. Empirical research has identified several conditions where it does. Let's take a closer look at the available evidence:

\section{Cross-Sections: Unfortunates Less Happy}

First of all there is a wealth of cross-sectional studies that found less happiness among people in adverse conditions than in favourable ones. 
For instance, people appear typically less happy in bad health than in good health and in isolation than in companionship. A problem in such comparisons is that living in either good or bad conditions may sometimes be a result of earlier happiness or unhappiness. Health and social integration depend to some extent on one's enjoyment of life (Veenhoven, 1988, 1989). Therefore it is better to focus on differences in living conditions that are clearly beyond the control of the individual.

Table 1 presents some data on the relation of happiness to uncontrollable hardship: 'widowhood', 'physical disability' and 'minority status'. In all cases adversity relates to a lower appreciation of life. The differences are greatest in the cases of recent personal disaster (miners' widows and recently paralyzed accident victims) and smallest in the case of long term disabled. This suggests that happiness drops drastically after serious adversity, but tends to revive in the long run. This is also more in line with the state-view on happiness than with the trait-view.

Follow-Ups: Change for the Worse Followed by Decline in Happiness Methodologically it is of course preferable to assess the effects of fortune and adversity longitudually. Table 2 presents some relevant findings. Happiness appears consistently lower after life change for the worse. The effects remain visible over periods longer than a year.

It is worth noting that several of these studies control the effect of earlier personality (Eels, Chiriboga, Heady). This reduces the effect of life change on happiness, but does not wipe it out. Here again we see that happiness-as-such must be conceptually distinguished from happiness-related-personality.

Apparently happiness is not insensitive to fortune or adversity. People do adjust their evaluation of life if the actual quality of their life changes. That is not to say that happiness fluctuates with every move to the better or worse. Only serious shifts seem to bring about a reorientation. 


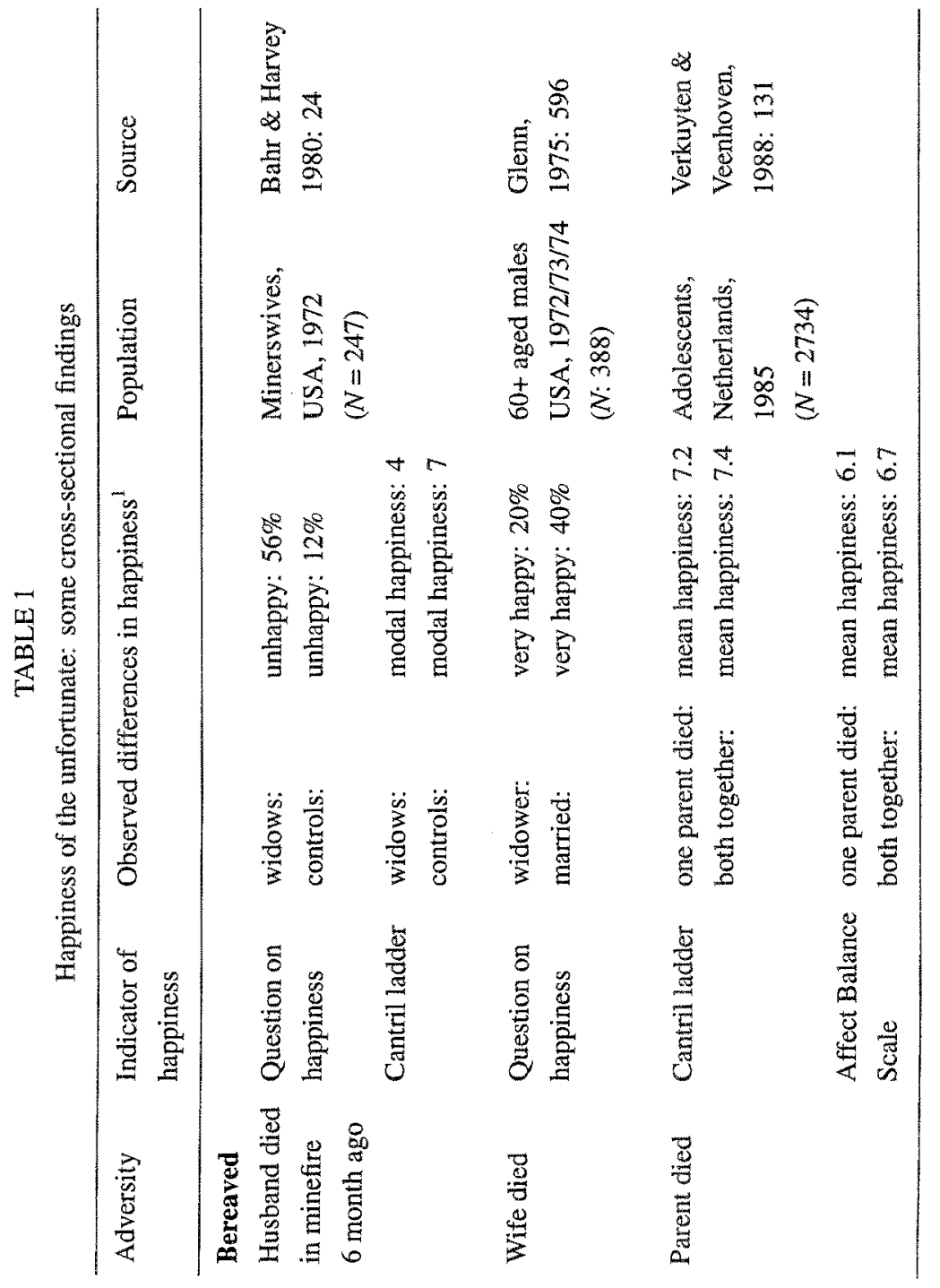




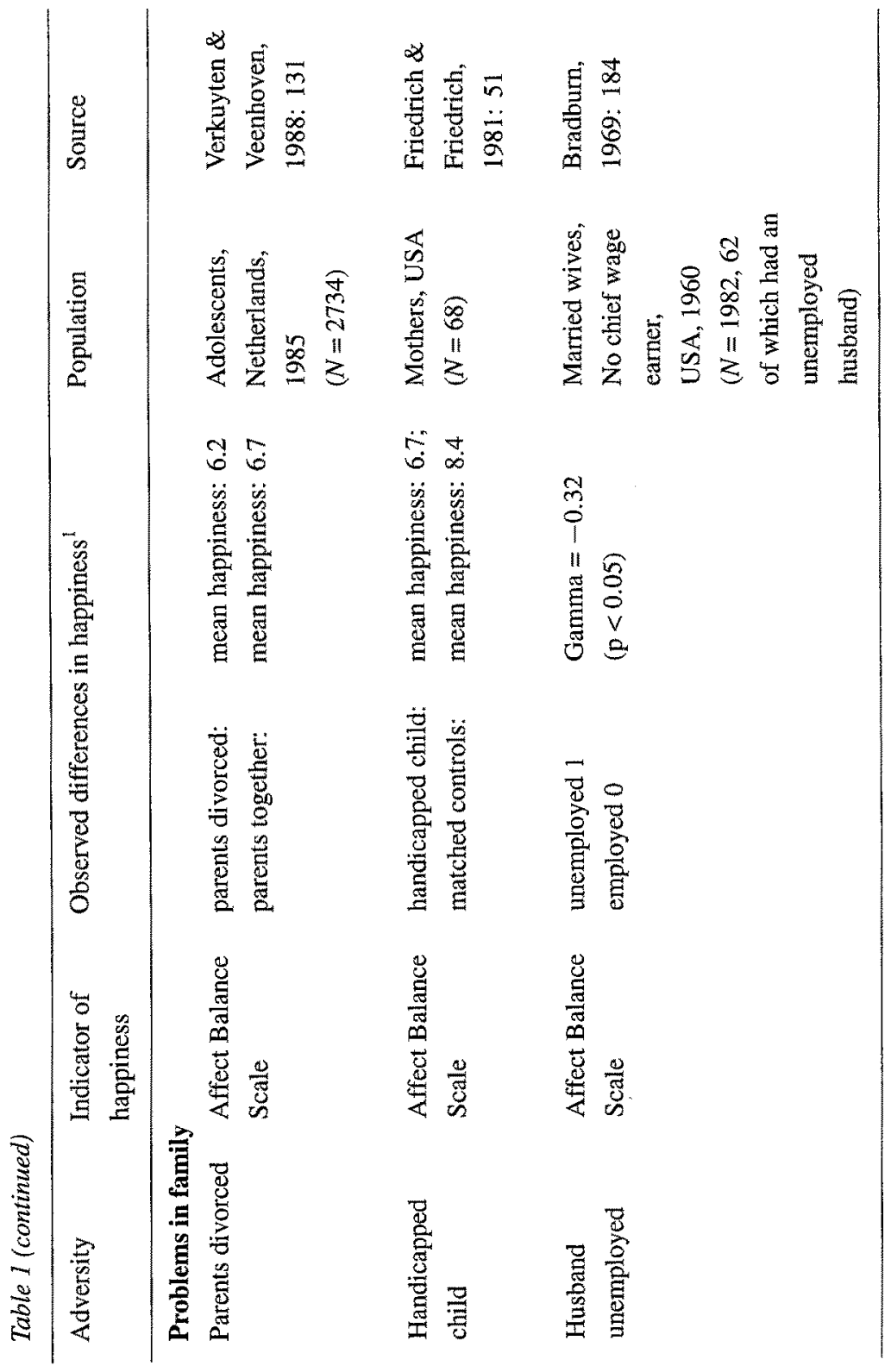


IS HAPPINESS A TRAIT?

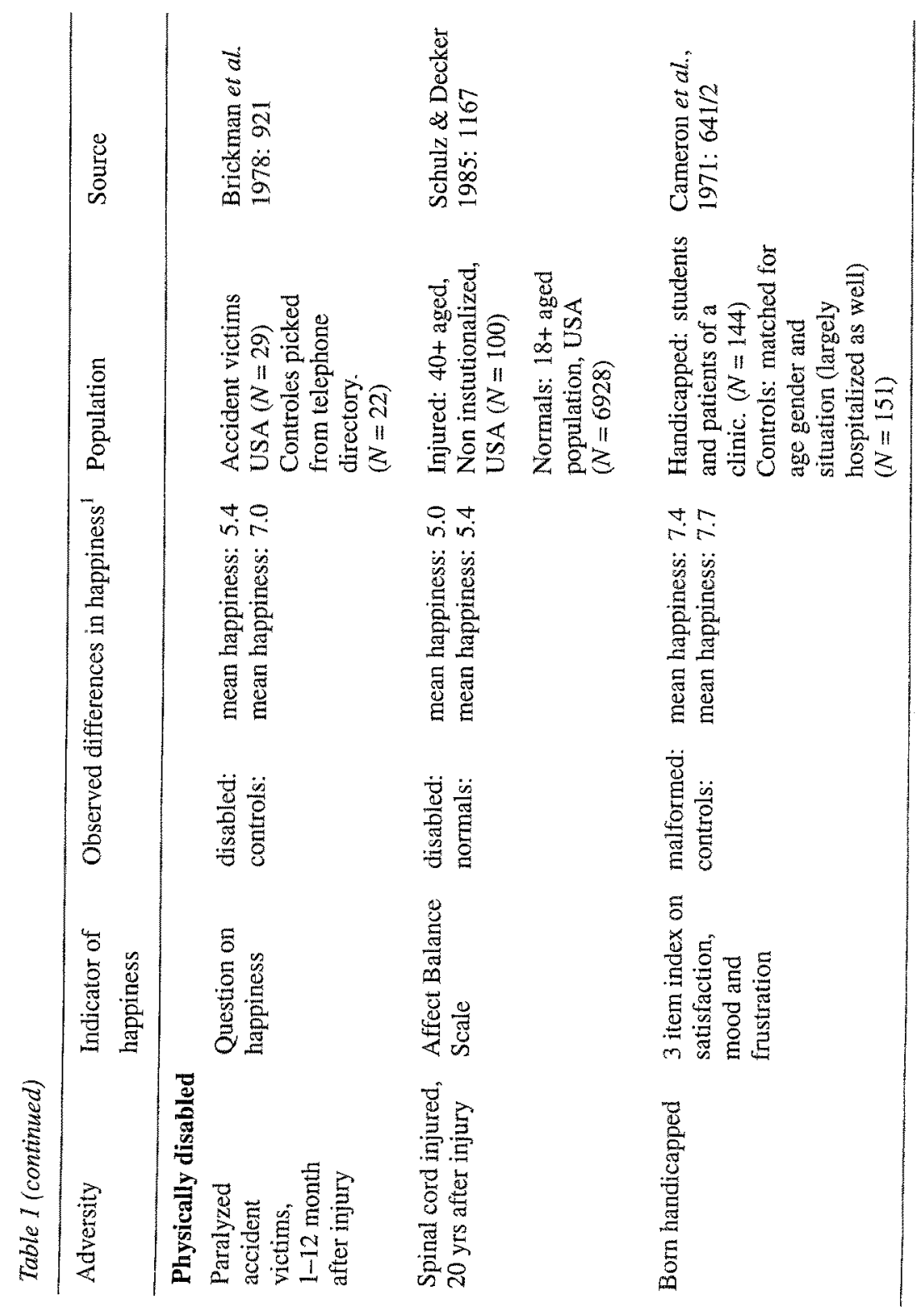




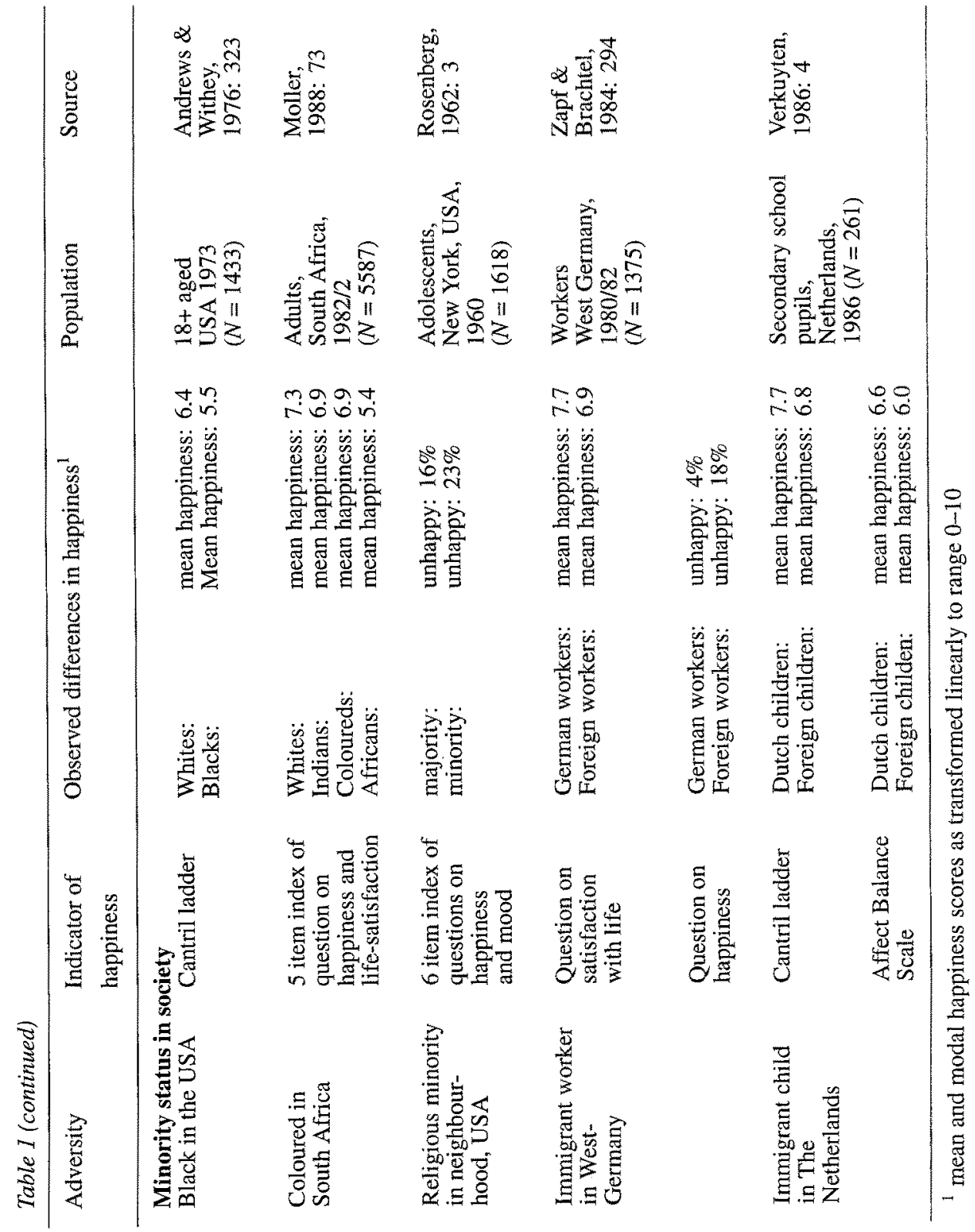




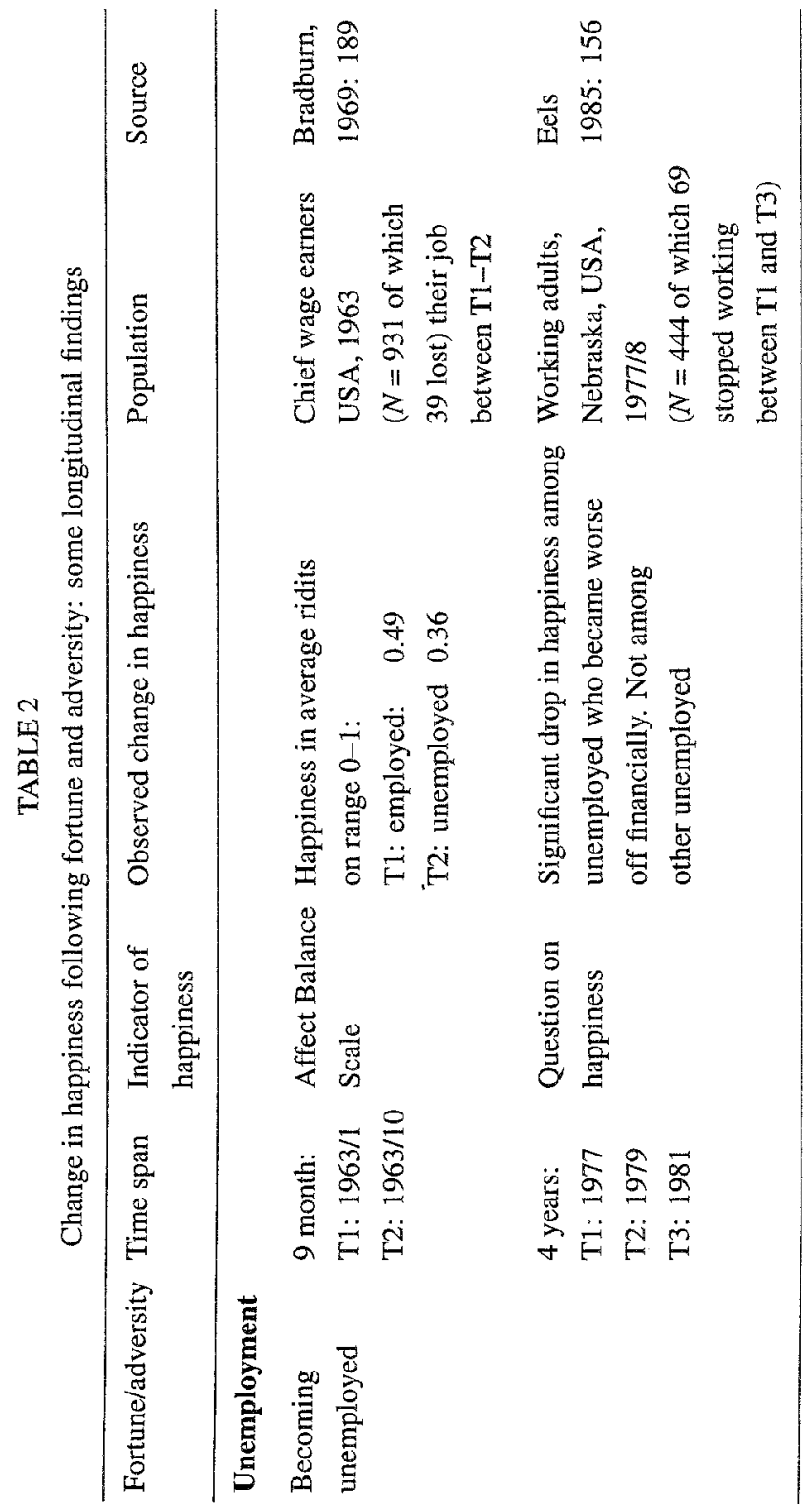




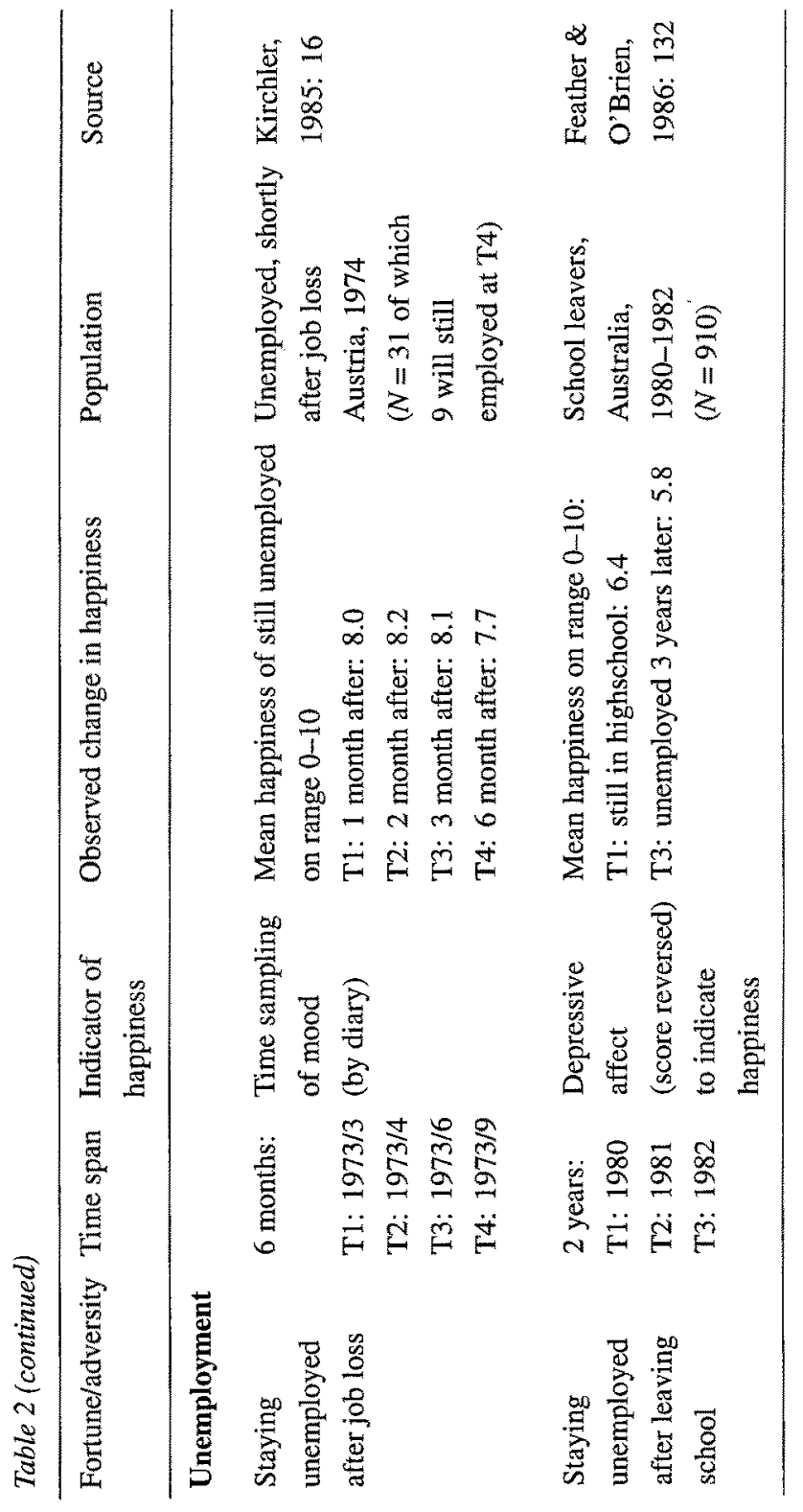




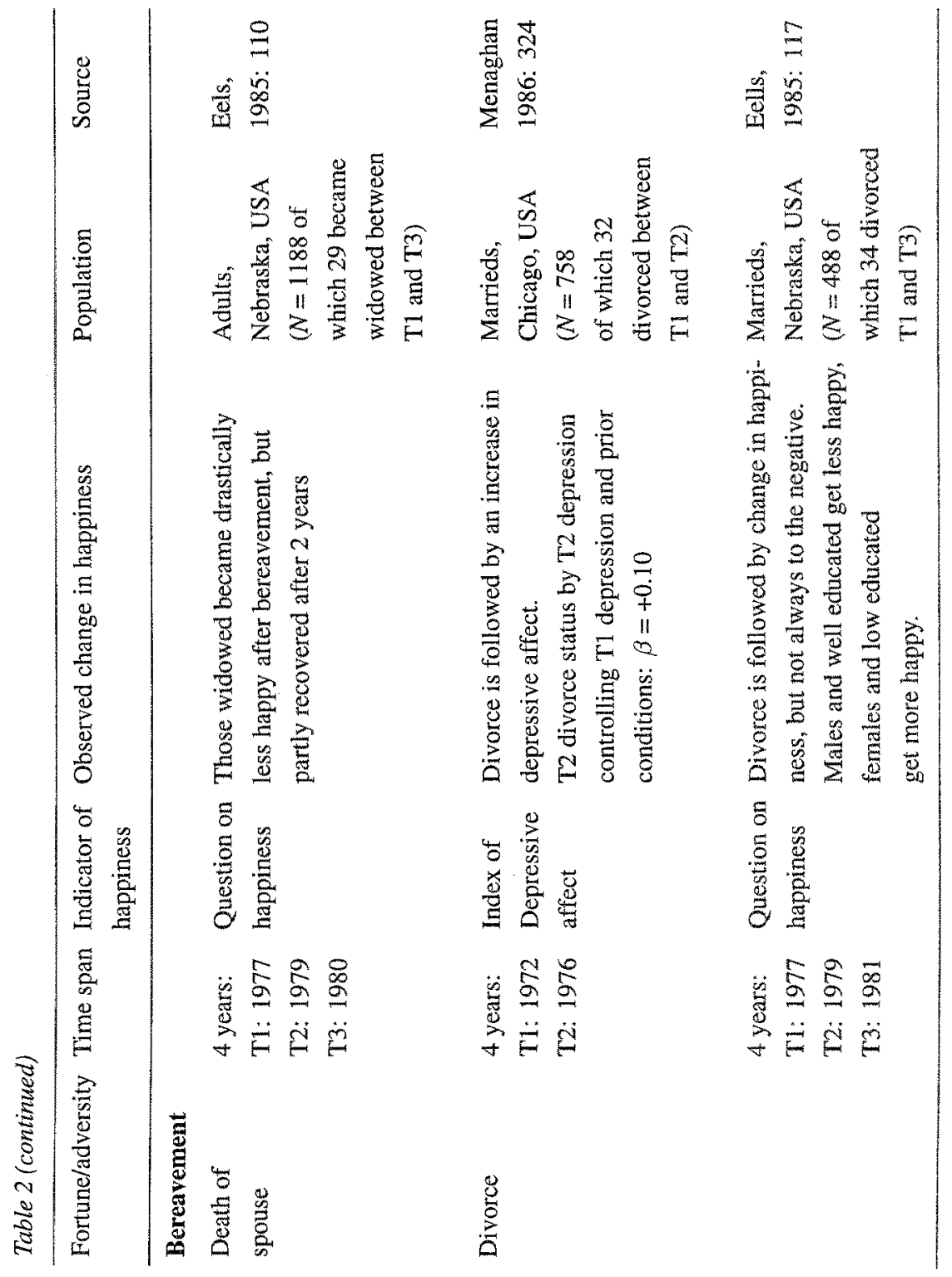




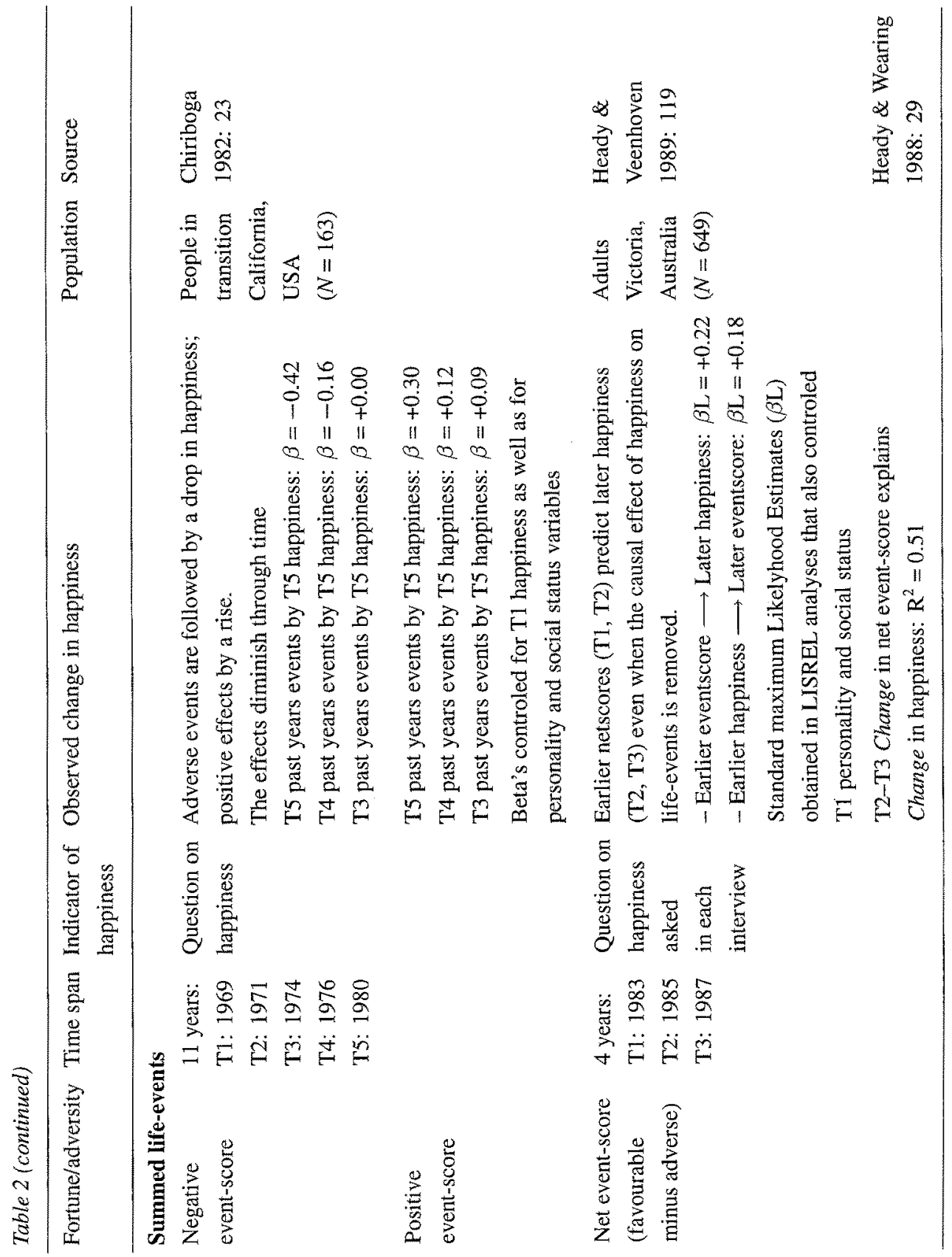




\subsection{Inner Causation: Is Happiness Mere Psychology?}

Trait theorists expect happiness to be temporally stable and situationally constant, because they believe that happiness is in some way "builtin'. They presume the existence of an inner disposition to enjoy life or not. Such disposition has been conceived in several ways: as an innate affective 'temperament' and as more or less acquired cognitive inclination. There is more speculation on this matter than solid data. Let us take a look at a few relevant investigations.

\section{Evidence for Existence of Innate Disposition}

The theory of innate happiness presumes that a tendency to appreciate life is in some way wired in; possibly in the neuro-chemical structure of the pleasure centres in the brain. Two testable predictions can be derived from this theory: The first is that people who are alike genetically must also be alike in happiness, irrespective of upbringing and variation in living conditions. This prediction can be tested by comparing twins: preferably mono-zygotic and di-zygotic twins reared apart and reared together. The second prediction is that people who were happy as children must be happy in adulthood as well. This hypothesis can be tested by following people from the beginning of life; preferably from infancy on.

\section{Comparison of Twins: Modest Correspondence in Happiness}

Several studies have compared the well-being of twins, but only one of these used an indicator that meets my demands for the valid measurement of happiness. That is a study by Wierzibicki (1986) which measured hedonic level by means of a mood diary. Hedonic level appeared to be more alike among mono-zygotic twins $(r=+0.55)$ than among dizygotic twins $(\mathrm{r}=+0.15)$. This findings suggests some genetic influence, though only a modest one; there are still considerable mood differences among identical twins. However, it is not sure that happiness-as-such is the genetic factor. The correlation can also be due to effects on happiness of other innate characteristics. 


\section{Follow-Up from Birth on; No Constancy in Happiness}

There is also only one long term study that has followed happiness from infancy on. This is the famous Berkeley Guidance Study (Schaefer and Bailey, 1963). In this developmental study hedonic level was assessed in the first years of life. Hedonic level was rated several times on the basis of expressive behaviour (laughing, crying etc.) These ratings were made at regular visits of mother and child to an obstetric clinic. Twelve ratings were made between birth and age 3 . These ratings appeared very stable over this period and could be regarded as a manifestation of inborn cheerfulness.

Between age 12 and 18 these same subjects went through several interviews and tests. Later on the protocols were used to derive indicators of adolescent happiness. A content analysis was performed by two independant assessors who charcterized the subject in several dimensions. Two of these dimensions were 'gloomy' and 'not cheerful'. These were combined in a sumscore that characterizes adolescent hedonic level. This score appeared unrelated to average baby-cheerfulness: $\mathrm{r}=-0.11(\mathrm{~ns})$. Another score representing adolescent contentment (discontented, unhappy, dissatisfied, complaints) appeared not related to baby-cheerfulness either: $r=-0.03$ (ns). Clearly this finding does not fit the prediction that people born happy remain happy. Yet there are methodological reasons to doubt the evidence: it is based on a very small number of girls $(N=11)$.

These two tests do not support the theory of innate happiness. That is in line with wider twin research, where cheerfulness does typically not appear as a genetically transmitted propensity. In fact Buss and Plomin (1984) identified only three temperaments for which an inherited contribution is likely to exist: emotionality, activity and sociability. These characteristics may facilitate happiness, but do not constitute happiness-as-such. Their effect on happiness is likely to be contingent to situations. 


\section{Evidence for Dominance of Psychological Determinants}

If innate dispositions to be happy are at best weak, it is still possible that we acquire a strong propensity of that kind. There is in fact a rich literature on how unhappy personalities develop. Traumatic experience and inappropiate learning are seen to produce distorted perception, unrealistic ambitions and inadequate coping. Chronic frustation and depressed affect is seen as the inevitable result. Even if external conditions are favourable, such inner handicaps would doom you to unhappiness. On the other hand good psychological health is depicted as a fairly sure ticket to happiness.

It is beyond doubt that inner characteristics influence happiness. Yet it is not so clear to what extent these dominate the appraisal of life, especially not among psychologically healthy people.

\section{External Factors Play a Role}

Several investigators have tried to grasp the relative impact of 'external' and 'internal' factors on happiness. External factors are usually split up in 'social resources' (income, education, status, social networks, etc.) and 'life-events' (illness, job loss, marriage, etc.). Internal factors are typically personality traits (extraversion, neuroticism, control orientation, etc.). The typical conclusion of such studies is that external factors explain less variance in happiness than one would expect and internal factors more.

The most sophisticated study of this kind is an Australian panel study by Heady and Wearing $(1989,1992)$, which also found that a sizeable part variance was explained by personality $(35 \%)$. Yet that study also showed that social resources and life events make a difference over and above personality, and explain $7 \%$ additional variance.

These results are sometimes presented as evidence for the claim that happiness is mere psychology. The data do not justify that conclusion however.

Firstly, external factors still influence happiness independantly of personality. Secondly, the variance explained by external factors is 
probably greater than $7 \%$ the $7 \%$ which is left when personality factors are entered first.

Thirdly, these data probably underestimate the actual effects in the populations studied. Systematic measurement error tends to attenuate correlations with external factors, while boosting correlation with psychological variables (Moum, 1988).

Lastly, and most importantly, this pattern may say more about the societies in which these investigations took place than about the nature of happiness. The observations are made in affluent egalitarian and peaceful societies. Inner factors differentiate better between happy and unhappy in these societies, because external conditions are fairly good and equally distributed. Probably the relative impact of psychological factors is smaller in a social context of poverty, deprivation and upheavel.

\section{'Inner Caused' Is not the Same as 'Immutable'}

If there is some 'inner' happiness propensity, the next question is what that consists of precisely. Two kinds of psychological characteristics have been mentioned in that context: dispositions that more or less 'constitute' happiness and characteristics that typically 'facilitate' its achievement. Let's consider what qualities may be involved, and whether these are likely to fix happiness at a certain stable level.

Constituents of happiness. A possible inner constituent of happiness is the tendency to take a rosy look at everything, sometimes refered to as the 'Pollyanna tendency'. Such a personality trait obviously manifests in a more positive evaluation of life-as-a-whole. Pollyannaism is indeed correlated to happiness, but not very strongly (Matlin and Gawron, 1979). By itself it can therefore not be an inner anchor that fixes evaluations of life to the same level.

Another possible inner constituent of happiness is an 'attitude' towards one's life. As noted above, evaluations of life may crystallize in a stable set of beliefs. However, if such attitudes exist at all, they are unlikely to remain fixed forever. Elsewhere I have suggested that people stick to the same evaluation only if they feel no pressures for a re-evaluation (Veenhoven, 1991: 17). This view supports the notion 
that there is some inner happiness-set whilst remembering the evidence that happiness is not insentive to environmental change. As yet that presumed process of 'freezing' and 'unfreezing' of happiness attitudes has not been examined empirically.

Facilitators of happiness. Commonly mentioned inner facilitators of happiness are 'extraversion', 'inner-control' and 'hardiness'. These personality traits are believed to add to the chances to realize one's ambitions. In that context Heady and Wearing (1992: 95) showed for example that extraversion facilitates intimate relationships, which in turn makes life more enjoyable. 'Neuroticism' typically induces a constant stream of negative life-events. Again we must realize that these effects are context bound; inner control may facilitate happiness in an individualized society that allows choice, but may be detrimental to it in confined situations.

Such inner facilitators of happiness are not necessarily fixed traits themselves. People can become somewhat more extraverted and less neurotic during their life. Social improvements such as better mental health care may stimulate such changes. In the long term better socialisation and a safer society will also make the next generations better equiped psychologically to cope with the problems of modern life.

In summary: Even if there is a marked inner disposition to be happy or not, that does not mean a better society cannot make people any happier.

\section{IS HAPPINESS A CULTURAL TRAIT?}

We now shift to the macro level and consider the claim that the appreciation of life is not really the result of an individual evaluation, but rather a reflection of collectively pre-conceived ideas. In this view happiness is a fixed social construction that has little to do with the variable realities of life. Therefore happiness would be largely insensitive to improvement of living conditions. 


\section{Differences in Happiness Between Nations}

During the last decades, questions on happiness have figured in representative surveys in many countries. Comparison of the responses reveals striking differences. Table 3 presents the average scores on equivalent questions in 30 nations around 1980. Average happiness tends to be lower in developing countries than in rich industrialized nations. Average happiness is highest in the Netherlands ( 7.63 on a 10-0 scale) and lowest in India (5.16). Among the rich nations considerable differences exist as well. For instance Italians and the Japanese take less pleasure in life than Australians and the Swedes.

Similar differences in happiness have been observed in other crossnation studies: in comparison between industrialized countries by Buchanan and Cantril (1953), Inkeles (1960, 1991) and Inglehart (1977/1992), and in global surveys by Cantril (1965) and Gallup (1976). These studies involved other indicators of happiness as well. The pattern of differences between countries appears almost the same when different measures of happiness are compared. See Veenhoven, 1993.

\section{Explanations of Differences in Happiness Between Nations}

There are three possible explanations for these differences: cultural bias in the measurements of happiness, differences in quality of living conditions and differences in view of life.

Measurement-bias. This explanation is that the seemingly identical questions on happiness work out differently accross countries. Possible sources of bias mentioned are: variation in social desirability distortion between countries, problems of precise translation and cultural variation in response tendencies. Elsewhere $I$ have considered the empirical evidence for these claims. None of them was supported by the data (Ouweneel and Veenhoven, 1991; Veenhoven, 1993).

Societal quality. This explanation assumes that the differences in response to questions about happiness reflect true variation in appreciation of life. This variation is attributed to differences in 'quality' of the living conditions societies provide to their citizens, such as food and shelter, safety, adequate care for children, fit between socialized and 
TABLE 3

Happiness in 30 nations around 1980

Taking all together, how happy would you say you are?

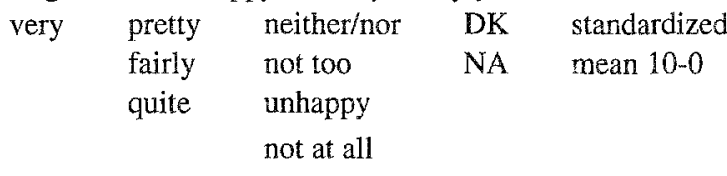

\begin{tabular}{lrrrrr}
\hline India & 6 & 31 & 62 & 1 & 5.16 \\
Greece & 10 & 40 & 48 & 2 & 5.60 \\
White Russia & 11 & 52 & 37 & - & 5.99 \\
Portugal & 11 & 70 & 21 & - & 6.18 \\
Korea (South) & 11 & 59 & 30 & - & 6.20 \\
Mexico & 26 & 34 & 37 & 3 & 6.31 \\
Italy & 10 & 65 & 23 & 2 & 6.47 \\
Philippines & 18 & 50 & 33 & - & 6.47 \\
Hungary & 11 & 66 & 22 & 2 & 6.60 \\
Spain & 20 & 58 & 22 & 2 & 6.84 \\
Japan & 15 & 62 & 16 & 8 & 6.94 \\
Germany (West) & 10 & 69 & 13 & 8 & 6.98 \\
Switzerland & 26 & 65 & 9 & - & 6.99 \\
South Africa & 27 & 54 & 18 & 2 & 7.07 \\
Luxemburg & 28 & 62 & 8 & 2 & 7.08 \\
Singapore & 32 & 58 & 9 & - & 7.15 \\
Brazil & 40 & 36 & 22 & 1 & 7.22 \\
France & 19 & 70 & 9 & 2 & 7.24 \\
Finland & 19 & 72 & 7 & 1 & 7.35 \\
Norway & 28 & 64 & 8 & - & 7.45 \\
USA & 31 & 60 & 9 & 1 & 7.55 \\
Belgium & 31 & 57 & 7 & 5 & 7.57 \\
Sweden & 29 & 66 & 4 & 2 & 7.62 \\
Netherlands & 44 & 50 & 6 & - & 7.63 \\
Denmark & 30 & 63 & 4 & 3 & 7.67 \\
N. Ireland & 39 & 55 & 5 & 1 & 7.74 \\
Britain & 38 & 57 & 4 & 1 & 7.74 \\
Australia & 34 & 61 & 4 & 1 & 7.75 \\
Canada & 35 & 61 & 4 & - & 7.76 \\
Ireland & 39 & 54 & 4 & 3 & 7.82 \\
Iceland & 43 & 53 & 4 & 1 & 7.96 \\
\hline Data: & 13 & & & \\
\hline
\end{tabular}

Data: Veenhoven, 1993, table 1.1.1 a+b+c

Standardized means computed on the basis of weights awarded to response categories by judges 
required behaviours and opportunities for self-actualization. Accounts of this kind have been proposed by Inglehart (1977) and Veenhoven (1984: ch.6). This explanation has also been used in accounts of differences in other aspects of well-being, such as cross-national differences in suicide, mental disorder and drug abuse (see e.g. Naroll, 1982). Basic postulates are that societies can be more or less effective in meeting human needs and that ineffective need gratification manifests itself in bad health, mental disturbance and dissatisfaction with life. In terms of trait theory this means that happiness is not consistent across situations.

National character. As we have seen the core of this explanation is that collective beliefs and values in a society mould individual evaluations of life. Some cultures are believed to predispose to a negative outlook on life, whereas others are said to foster a positive view. Various cultural differences have been mentioned in this context: Inglehart (1990: 30) suggests "that the culture component of these differences reflects the distinctive historical experience of the respective nationalities. Long periods of disappointed expectations give rise to cynical attitudes. These orientations may be transmitted from generation to generation through pre-adult socialisation". Religion has also been mentioned in this context. Calvinism is often said to breed unhappiness, because of its gloomy outlook on the future and its moral rejection of lust.

Whatever the cultural mechanisms presumed, the underlying psychological assumption in all these reasonings is that happiness is largely a cognitive matter that is only loosely linked to real life-experience.

If happiness is indeed a matter of national character, we can expect that it meets the three trait criteria at the collective level. This section examines whether that is the case or not. First I will inspect whether average happiness in countries remains the same over the years (temporal stability, section 3.1). Next I consider whether average happiness in nations is independant of the quality of living conditions in the country (situational consistency, section 3.2.). Finally I test some implications of the theory that happiness is a matter of collective outlook (inner causation: section 3.3.). 


\subsection{Temporal Stability: Do (Un)Happy Countries Remain (Un)Happy?}

Time-series on average happiness are only available for some industrialized countries. In the USA happiness has been followed since 1945, in Japan since 1958 and in the EC countries since 1974. At the individual level that would be a significant time-lag, but at the societal level it is only a very short period. Next to these time-series (yearly surveys that use the same question) there are some more incidental data that allow a look at the temporal stability of public happiness. Data on happiness in nations were found in Veenhoven (1993).

\section{Relatively Stability}

The first comparative study on happiness in nations was performed in 1948 by Buchanan and Cantril (1953) among 9 countries. These same countries figure in the 1980 World Value Study. Though not identical, the measures of happiness (life-satisfaction) are quite alike. Table 4 presents the rank-orders. Four countries appear to have remained in the same position, five countries changed position by two or three steps. Norway and Mexico fell back, whereas Britain, France and Germany advanced in relative happiness. The rank-order correlation is +0.73 .

\section{Absolute Stability}

In several countries happiness has remained at about the same level during the last decades. The USA is one of these: in $194836 \%$ of the Americans characterized themselves 'very happy' and 54\% 'fairly happy'. Forty years later (1988) these percentages were $34 \%$ and $57 \%$ (Veenhoven, 1993: table 1.1.1a). In Japan happiness has remained at the same level as well in the years 1958-1988 (Veenhoven, 1993: table 1.2.1a).

However, there are also some countries where happiness has changed considerably. For instance, in $195426 \%$ of the Germans characterized themselves as unhappy, whereas in 1984 only $10 \%$ did so (Veenhoven, 1993: table 1.2.3). Likewise in Brazil ratings on the Cantril ladder rose from 4.6 in 1960 to 6.2 in 1975 (Veenhoven, 1993: table 1.3.1). Both 
TABLE 4

Relative temporal stability of average happiness in nations

\begin{tabular}{lcc}
\hline country & rank order of happiness & \\
& 1948 & 1981 \\
\hline Australia & 2 & $2 / 3$ \\
Britain (Great) & 9 & 7 \\
France & $7 / 8$ & 5 \\
Germany (West) & 4 & 1 \\
Italy & $7 / 8$ & 8 \\
Netherlands & 5 & 6 \\
Norway & 1 & $2 / 3$ \\
Mexico & 6 & 9 \\
USA & 3 & 4 \\
\hline rank order-correlation: & $\mathrm{r}_{s}=+0.73(\mathrm{p}<0.01)$ & \\
\hline
\end{tabular}

Data: Veenhoven, 1993, table 1.2.1a and 1.2.2b.

Absolute values are not comparable, because questions were not identical

these increases in happiness occurred in a period of marked economic development.

During the last decade happiness has increased slightly in most European countries. This increase is most pronounced in the originally least happy nations (France, Greece, Italy, Spain). This catching up of Mediterranean nations with North-West Europe is visible in several indicators of happiness (Veenhoven 1993: tables 1.1.1b, 1.1.2b and 2.2).

Again we must keep in mind that this data come, for the greater part, from affuent countries in an era of stability. The average happiness of citizens may be more variable in countries that provide less buffers and experience more turmoil. 


\subsection{Situational Consistency: Are People Equally Happy in Good and Bad Countries?}

If happiness is a cultural stereotype rather than an individual evaluation, we can expect that it is largely unrelated to the quality of living conditions in the country. Consequently countries that provide good living conditions will not stand out by higher average happiness than countries of poor living conditions. Likewise changes to the good or the bad in countries will have little or no effect on the average happiness of citizens.

\section{Cross-Sections: Higher Happiness in Countries that Provide Better Living Conditions}

To check the first prediction I gathered data about the quality of living conditions for the 30 countries of which we have comparable happiness scores (the countries enumerated in table 3). I found comparable performance indicators on the material comfort these nations provide for their citizens, on the freedom, their political system allows, on the degree to which they save the pains of inequality and the degree to which they provide their citizens access to knowledge. Details about measurement can be found in appendix 2 . These country characteristics were correlated with average happiness. The results are presented in table 5. All performance indicators appear to be related to average happiness. Economic affluence is the strongest predictor. Yet social equality and education relate to happiness independant of income per capita. Together they explain no less than $80 \%$ of the variance! An analysis of responses to another question (10 step life-satisfaction) in a slightly different nationset yields a similar result.

\section{Follow-ups: Slight Effects of Economic Change in Rich Nations}

A test of the prediction that happiness remains the same through prosperity and adversity requires time-series on happiness over periods in which marked changes occur such as wars, revolutions or economic crises. However the available time-series concern a period of peace and 


\section{TABLE 5}

Average happiness and living conditions in 30 nations around 1980

\begin{tabular}{llll}
\hline Living conditions in countries & $\begin{array}{l}\text { Correlation (r) with average happiness in countries } \\
\text { listwise }(N=27) \\
\text { zero order }\end{array}$ & $\begin{array}{c}\text { RGDP controlled } \\
\text { pairwise } \\
(N 23 \text { to } 27)\end{array}$ \\
\hline Material Comfort & $+0.71^{*}$ & - & $+0.70^{*}(N=27)$ \\
- Real income per capita & $+0.60^{*}$ & +0.24 & $+0.53^{*}(N=26)$ \\
- Social security & & & \\
Social Equality & $+0.77^{*}$ & $+0.67^{*}$ & $+0.62^{*}(N=22)$ \\
- Women's emancipation & & & \\
Freedom & $+0.55^{*}$ & +0.28 & $+0.55^{*}(N=27)$ \\
- Freedom of press & $+0.57^{*}$ & +0.02 & $+0.61^{*}(N=23)$ \\
- Political democracy & & & $+0.71^{*}(N=27)$ \\
Access to Wisdom & $+0.84^{*}$ & $+0.65^{*}$ & $+0.54^{*}(N=27)$ \\
- Education & $+0.54^{*}$ & +0.07 & \\
- Media attendence & & & \\
\hline Total variance explained: & & & \\
$\mathrm{R}^{2}$ & $0.80^{*}$ & &
\end{tabular}

Data: Happiness: Table 3. Country characteristics: Appendix 2; ${ }^{*} p=<0.01$

rather smooth economic growth. This seriously limits the possibilities to check the hypothesis.

Elsewhere I have considered the effects of postwar economic growth on average happiness in countries (Veenhoven, 1989). I observed that a doubling of the material standard of living was not parallelled by a doubling of average happiness in the already rich USA. Yet economic growth was followed by greater happiness in originally less affluent nations such as Brazil and also in West European nations. These latter cases falsify the theory that happiness is a national character trait. Together the findings suggest that people get happier when material 
living conditions improve, but that these increments are subject to the law of diminishing returns.

Together with Sasqia Chin Hon Foei I have also investigated the effects of the 1980-1982 economic recession in the EC countries. We found that this minor recession was followed by a minor drop in happiness at a 1 year interval. These effects were particularly clear in the countries that provide relatively little social security (e.g. Ireland), which means that they were least able to buffer the financial effects of economic fluctuation (Chin Hon Foei, 1989). A similar effect has been observed in Japan: the 1975 oil crisis was followed by a clear dip in average happiness. (Prime Ministers Office, 1987). Again it is clear that average happiness in the country is not a static matter.

\subsection{Inner Causation: Individual Happiness Conditioned by Collective Outlook?}

The theory that individual happiness is largely a matter of collective outlook can be checked in two ways: one way is to inspect whether happy and unhappy nations differ in relevant values and beliefs. Another way is to assess whether members of a same culture tend to be equally happy in spite of difference in living conditions.

\section{Difference in Outlook Between Happy and Unhappy Nations}

Above three hypotheses were mentioned in connection with national differences in outlook that may cause dissimilarity in happiness: 'moral appreciation of happiness', 'cynical attitudes' and 'calvinist religion'. Below I will test these hypotheses using data from the 1980 World Value Study.

\section{Moral Appreciation of Happiness Unrelated to Level of Happiness}

As suggested above, the differences in happiness between countries may be due to a difference in valuation of happiness: happiness acceptant cultures may allow more enjoyment of the same things, thereby fostering a more positive view on life. If so, happiness must be higher in countries that cherish happiness than in countries that deprecate it. 
Testing this prediction requires that we measure moral appreciation of happiness in countries. I constructed an indicator of that matter on the basis of survey data. The European Value Study involved many questions about value preferences. In an earlier analysis of these data Halman (1987) distilled several value dimensions and computed average scores. Some of these dimensions are indicative of moral appreciation of pleasure and satisfaction. One such dimension is the tendency to approve of lust and pleasure as a guiding principle in matters of family, marriage, and sexuality. Halman refers to this dimension as 'Egoism'. A second dimension concerns enjoyment and comfort in the realm of work ethics. Halman refers to it as the 'Comfort/Materialistic' dimension. I added these two factor scores for each country and regarded the sum as a proxi of 'Moral Hedonism' in the country.

This indicator of moral hedonism is crossed with the level of happiness in the country. See figure 3. Average happiness appears not higher in the countries where hedonic values are most endorsed $(r=$ +0.03 ). For instance, the three least happy nations are respectively low, medium, and high on hedonic value orientation. It is of course possible that other measures and other country-sets yield different results. Yet it must be noted that this explanation failed its first test.

\section{No Consistent Attitudinal Cynism in Unhappy Nations}

As noted above, Inglehart suggests that the relatively low happiness in the Mediterranian countries in Europe is the result of 'cynical attitudes' that may be rooted in earlier generations' disappointments. If that is true, unhappy countries must appear to be more cynical. The European Value Study involves two indicators that are relevant in this context: mistrust in fellow man and mistrust in society.

Mistrust in one's fellow men was measured by a single direct question: In general do you think that most people can be trusted? The responses were scored (1) can be trusted, (2) don't know and (3) better be careful. I crossed the average mistrust score per country with average happiness. In line with the hypothesis mistrust is highest in the least happy countries: $r=-0.59$.

Mistrust in society was measured by trust in social institutions. Respondents were asked to rate their trust in the following ten insti- 


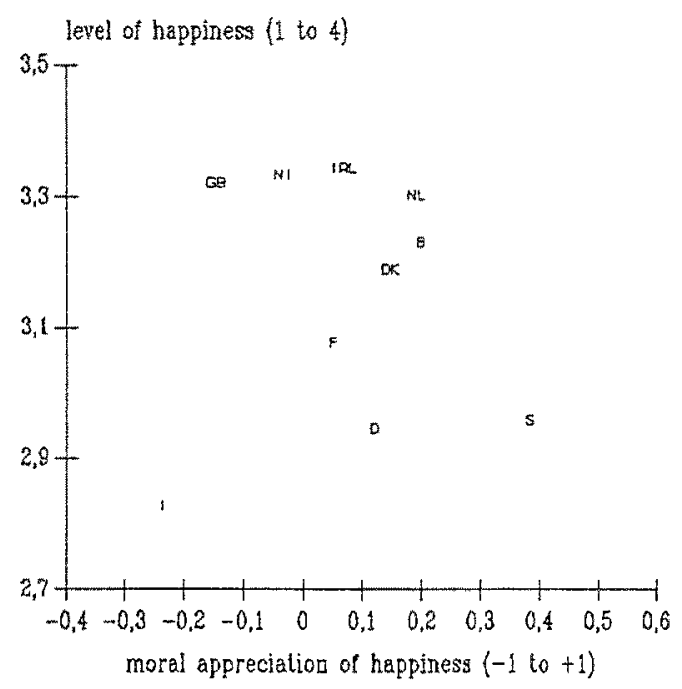

Fig. 3. Happiness and moral appreciation of happiness 9 nations around 1980. Data: European Value Survey (Halman et al., 1987) $\mathrm{r}=+0.00$.

tutions: the church, the army, the school, the law, the press, unions, the police, parliament, civil servants and big business. For each country an average trust score was' computed. These scores were converted to mistrust and crossed with happiness. In this case a positive correlation appears. Mistrust is higher in the most happy nations: $r=+0.35$.

Inglehart's prediction is thus only partially confirmed: a cynical attitude towards fellow man is indeed related to unhappiness in the country, but a cynical attitude towards society is not. The absence of a correlation with mistrust in society is the more noteworthy in the context of Inglehart's suggestion that cynical attitudes result from earlier social disorganisation. If so, that must manifest itself in sceptism about society in the first place.

\section{Calvinist Countries not Less Happy}

The claim that the cultural heritage of Calvinism is predisposed to unhappiness can be easily checked. A look at table 3 shows that the countries where Protestantism dominates belong typically to the hap- 

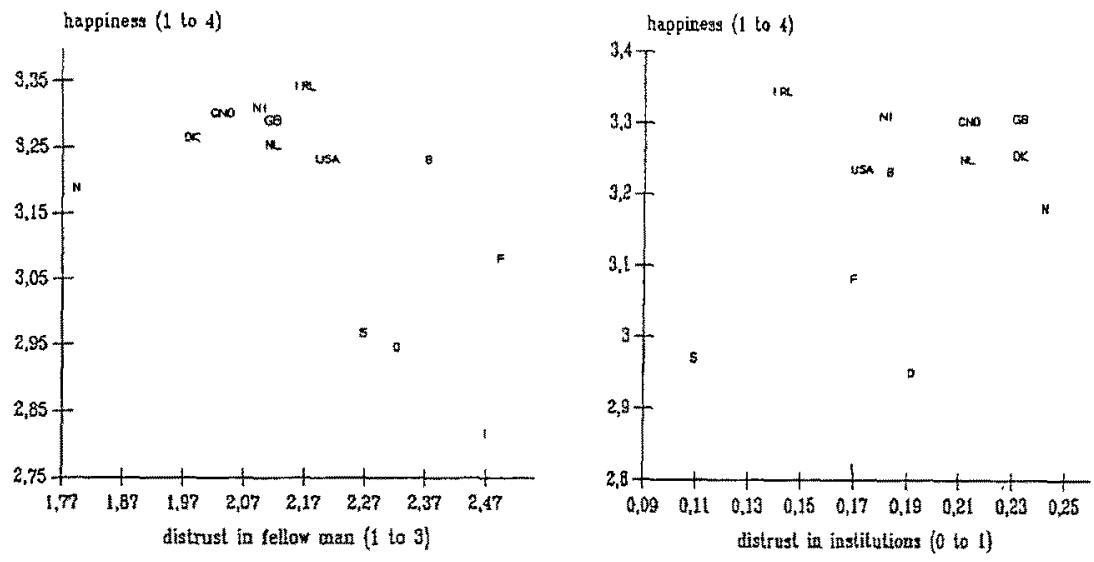

Fig. 4. Happiness and attitudinal cynism 13 nations around 1980.

Data: European Value Survey: Halman, 1991.

piest group: Britain, Denmark, Iceland, Norway and Sweden. On the other hand happiness is typically low in Roman Catholic countries such as Belgium, France, Italy and Spain. Does that mean that the reverse is true, but that happiness is still conditioned by religious outlook? That does not seem to be the case either. The happiest country in table 3 is The Netherlands, which is religiously mixed.

\section{Homogenity in Happiness within Cultures}

If individual evaluations of life are heavily conditioned by collective outlook (rather than by individual reference), we can expect much homogenity in happiness within cultures. That homogenity must appear in similarity of happiness across social categories in countries. It must also manifest itself in similarity across borders between people reared in the same culture. For instance, the happiness of migrants must remain close to the level in their mother country and there must be little differ- 
ence in average happiness between nations that share the same cultural heritage. Below I report some tests of these inferences.

\section{Happiness of Students not Always Similar to Happiness of General Population}

If individual happiness is largely a matter of collective values and beliefs, we can expect that all citizens in a country are effected by the prevailing outlook. Country differences observed in general population samples must then be reproduced in comparisons between specific social categories. For instance, if we focus on rich people only, we must find about the same difference in happiness between India and the Netherlands as reported in table 3, supposing that in both countries the rich look at their life through the same culturally coloured glasses as the non-rich.

This implication can best be tested by splitting up the data in table 3 by income, age and gender. However, this is easier said than done. Not all the data sets are available and categorizations are not identical. An easier way to do the same job is to compare average population means with mean happiness among university students. Data about happiness in university students in most of the countries in table 3 is available from a 39 nation study by Michalos (1991). University students are an attractive category for comparison in this context. Their social position is fairly similar in all countries.

The country differences in happiness among students appear not identical to the differences among general population samples. The differences are smaller and the rank order is not the same. In India and Mexico students are fairly happy, whereas the general population is not. In Thailand students are relatively least happy, whereas the general population average is modal. There are also consistent cases however: the Netherlands, USA, UK at the positive side and Japan, Korea and Greece at the negative side. These cases produce a correlation of +0.42 in this nation set. (Data not shown).

This finding means that shared views can at best determine average happiness in a country to a limited extent. Probably they do even less. The correspondence in happiness between students and the general population depends obviously on other things as well, in particular on 
societal characteristics, such as economic development, freedom and equality. Remember table 5.

Happiness of Migrants is Closer to Happiness in Homeland than to Happiness in Country-of-settlement

If Inglehart is right in that happiness is largely determined by "socialized attitudes" that are "transmitted through generations", we can expect that the happiness of migrants will be more similar to happiness in their country-of-origin than to average happiness in the country-ofsettlement. Though living conditions may be different in the new country (mostly better), they are looked at from the same cultural perspective.

This prediction was tested in an analysis of studies in Australia and West Germany. Two Australian studies in the 1980's assessed the happiness of migrants from Britain, Greece, Germany, Italy, Netherlands and Yugoslavia. Data are summarized in table 6. Migrants appear about as happy as native Australians and differences among migrants are small. Yet table 6 also shows that there are marked differences in happiness between countries of origin. Happiness is clearly lower in Greece and Italy than in Australia. Only Britain, Ireland and The Netherlands are at the same level. Clearly migrants from unhappy countries are not saddled with a pessimistic outlook that prevents them from enjoying life as much as their new compatriots. A similar tendency can be observed in the results of two studies in West-Germany. Here again the happiness of migrants (from Greece, Italy, Spain, Turkey and Yugoslavia) is closer to the average in the host country than to the average in the mother land.

Cultural trait theory also predicts that the hierarchy of happiness in home countries must be reproduced among migrants. For that purpose rank order correlations were computed both in Australia and in West Germany, and the results are contradictary: in one study no correlation $(r=+0.10$ and +0.03$)$, in the other a sizable (but still statistically insignificant) correlation: $r=+0.58$ and +0.50 .

\section{Happiness Is not the Same in East and West Germany}

The theory that happiness is a cultural trait would also predict that East and West Germans are about equally happy. Germans share the same 


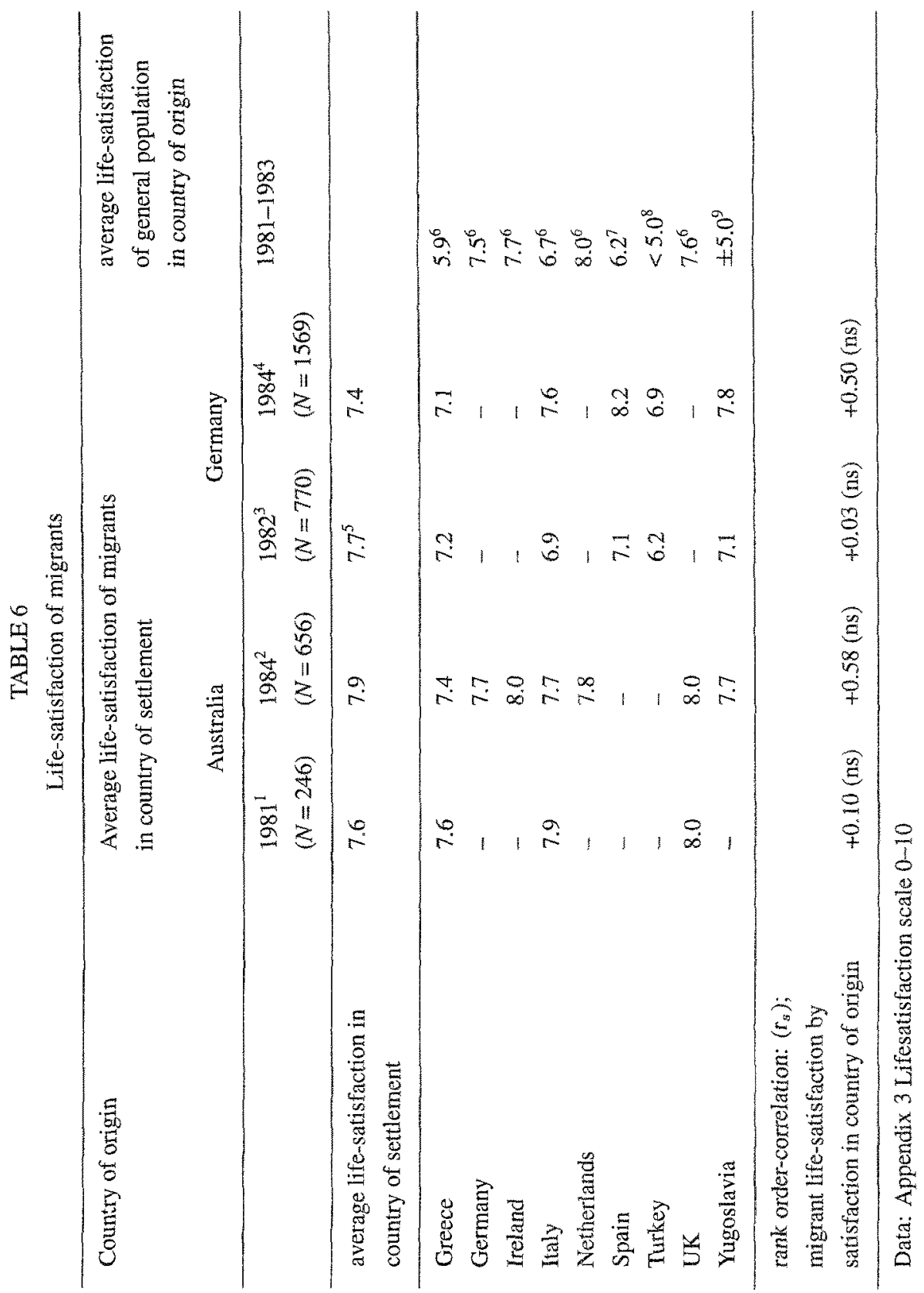


cultural heritage and speak the same language. The political separation lasted only half a generation and did not cut off all cultural exchange.

The data clearly falsify that prediction. East Germans are less happy than West Germans: in 1990 scores on a 11-step satisfaction scale were respectively 6.0 and 7.3 in 1991 (Landua 1992: 33).

The current difference can be explained by poorer living conditions in former East Germany. In the following decade successful resurrection will probably erase the dissimilarity in happiness.

Obviously one can think of more specifications of the theory that happiness is a matter of cultural outlook. In fact it is quite difficult to test such a broad claim exhaustively. For the time being we must conclude that these first tests provide little support.

\section{DISCUSSION}

The reason for this inquiry was the question whether improvement of society can make citizens any happier. That question can now be answered affirmatively. Happiness is not so invariable a matter that it is insensitive to improvement or deterioration of living conditions. Though people do not change their judgement of life every day at every whim of fate, they do adjust the evaluation periodically and take major life-changes into account. As such, happiness is a suitable endgoal for social policy (though not necessarily the only one) and a useful indicator of policy success.

This leads us to ask the question why is current opinion to the contrary? Four reasons seem to be involved, two technical distortions and two ideological fallacies.

Firstly, the bulk of the available research findings seemed to indicate that people tend to remain equally happy. As we have seen most followup studies considered relative stability over short periods and found surprisingly little change. The few long term studies seem to have been snowed under. Absolute stability has not yet been considered.

Secondly, high relative stability rates have been found in studies that use measures which tap broader aspects of psychological well-being 
than just happiness. The much used Life-Satisfaction Index (Neugarten et al, 1962) for instance also involves items about 'planning mindedness', 'self-respect' and 'views on social progress'. These attitudes may be more fixed than happiness is.

Thirdly, the theory that happiness is a trait provides an easy explanation for the common observation that happiness is hardly linked to social positional variables such as income, education, sex and age: at least not in modern western nations. This finding was a surprise for most investigators who had hoped to demonstrate psychological consequences of social inequality. They were reluctant to conclude that present day western society is apparently so equal and affluent that traditional cleavages hardly matter any more. Therefore they rather attributed the non-difference to a presumed psychological insensitivity of the outcome-measure.

Lastly, there is sceptism about happiness that is rooted in longstanding discussions about value priorities. The Utilitarian position that happiness marks the ultimate value is not accepted by everybody and advocates of alternative value priorities tend to denounce happiness as 'fleeting' 'relative' and 'spoiling'. The idea that happiness is 'fixed' fits that negative view. Indications in that direction are therefore readily accepted.

\section{CONCLUSION}

Contrary to current opinion happiness is no trait; neither a personal trait nor a cultural trait. Happiness does not meet the classic three definitions of trait.

Firstly, happiness is not temporally stable. Individuals revise their evaluation of life periodically. Consequently their happiness rises and drops, both absolutely and relatively. Average happiness of nations appears not immutable either. Though stability prevails, there are cases of change.

Secondly, happiness is not situationally consistent. People are not equally happy in good or bad situations. Improvement or deterioration of life is typically followed by changes in the appreciation of it. This 
is also reflected at the collective level. Average happiness is highest in the countries that provide the best living conditions. Major changes in condition of the country affect average happiness of its citizens.

Lastly, happiness is not entirerly an internal matter. It is true that happiness roots to some extent in stable individual characteristics and collective orientations, but the impact of these inner factors is limited. They modify the outcome of environmental effects rather than dominating them.

These findings knock the bottom out of the argument that happiness is too static a matter to be influenced by social policy. There is thus still sense in pursuing greater happiness for a greater number.

The findings also refute the related claim that happiness is not a useful social indicator. Though happiness may be a slowly reacting instrument, it does reflect long-term change for better or worse.

APPENDIX 1

Overtime-correlation of happiness in 26 longitudinal studies

\begin{tabular}{|c|c|c|c|c|c|}
\hline Subjects & $\begin{array}{l}\text { Happiness } \\
\text { measure }\end{array}$ & $\begin{array}{l}\text { Happiness } \\
\text { variant }^{1}\end{array}$ & $\begin{array}{l}\text { Time } \\
\text { span } \\
\text { in } \\
\text { years }\end{array}$ & $\begin{array}{l}\text { Overtime- } \\
\text { correlation } \\
\text { (in r) }\end{array}$ & $\begin{array}{l}\text { Bibliografical } \\
\text { source }\end{array}$ \\
\hline $\begin{array}{l}60+\text { aged white } \\
\text { unmarried females } \\
N=42\end{array}$ & $\begin{array}{l}10 \text { item Affect } \\
\text { Balance Scale }\end{array}$ & A & 3 & +0.38 & $\begin{array}{l}\text { Adams, } \\
\text { 1988: } 35\end{array}$ \\
\hline $\begin{array}{l}\text { Highschool pupils, } \\
\text { USA. } \\
\text { Followed from age } \\
12 \text { to } 15 \\
N=2213\end{array}$ & $\begin{array}{l}6 \text { item index of } \\
\text { questions on } \\
\text { happiness } \\
\text { and mood }\end{array}$ & $O$ & $\begin{array}{l}1 \\
1,5 \\
2,5 \\
3,5\end{array}$ & $\begin{array}{l}+0.54 \\
+0.45 \\
+0.43\end{array}$ & $\begin{array}{l}\text { Bachman et al., } \\
1970 \\
\text { (overtime- } \\
\text { correlations pro- } \\
\text { vided by author) }\end{array}$ \\
\hline
\end{tabular}


Appendix I (continued)

\begin{tabular}{|c|c|c|c|c|c|}
\hline Subjects & $\begin{array}{l}\text { Happiness } \\
\text { measure }\end{array}$ & $\begin{array}{l}\text { Happiness } \\
\text { variant }^{1}\end{array}$ & $\begin{array}{l}\text { Time } \\
\text { span } \\
\text { in } \\
\text { years }\end{array}$ & $\begin{array}{l}\text { Overtime- } \\
\text { correlation } \\
\text { (in r) }\end{array}$ & $\begin{array}{l}\text { Bibliografical } \\
\text { source }\end{array}$ \\
\hline $\begin{array}{l}\text { Highschool pupils, } \\
\text { USA. } \\
\text { Male and Female } \\
\text { Followed from age } \\
10 \text { to } 35 \\
N=160 \\
\text { Largely same sub- } \\
\text { jects as studied by } \\
\text { Tuddenham } \\
\text { (below) }\end{array}$ & $\begin{array}{l}\text { Rating } \\
\text { of cheerfulness } \\
\text { (vs gloomy) } \\
\text { on the basis of } \\
\text { interview } \\
\text { protocols }\end{array}$ & A & $\begin{array}{l}15 \\
15\end{array}$ & $\begin{array}{l}+0.57 \mathrm{M} \\
+0.50 \mathrm{~F} \\
+0.26 \mathrm{M} \\
+0.36 \mathrm{~F}\end{array}$ & $\begin{array}{l}\text { Block, } \\
\text { 1971: } 302-307\end{array}$ \\
\hline $\begin{array}{l}18+\text { aged, } 2 \text { com- } \\
\text { munities, USA } \\
N=547\end{array}$ & $\begin{array}{l}\text { Single } \\
\text { question on } \\
\text { happiness }\end{array}$ & 0 & 0,6 & +0.48 & $\begin{array}{l}\text { Bradburn \& } \\
\text { Caplovitz, } \\
\text { 1965: } 90^{3}\end{array}$ \\
\hline $\begin{array}{l}\text { People in transition, } \\
\text { USA. } \\
\text { High and low } \\
\text { stressed } \\
N=72\end{array}$ & $\begin{array}{l}10 \text { item Affect } \\
\text { Balance Scale }\end{array}$ & A & $\begin{array}{l}2 \\
5 \\
7 \\
11\end{array}$ & $\begin{array}{l}+0.43 \\
+0.40 \\
+0.44 \\
+0.20\end{array}$ & $\begin{array}{l}\text { Chiriboga, } \\
1989: 65\end{array}$ \\
\hline $\begin{array}{l}\text { People in transition, } \\
\text { USA } \\
\text { Males: } N=64 \\
\text { Females: } N=76\end{array}$ & $\begin{array}{l}\text { Single } \\
\text { question on } \\
\text { happiness }\end{array}$ & $\mathrm{O}$ & $\begin{array}{l}11 \\
11\end{array}$ & $\begin{array}{l}+0.03 \mathrm{M} \\
+0.18 \mathrm{~F}\end{array}$ & $\begin{array}{l}\text { Chiriboga, } \\
1982: 23\end{array}$ \\
\hline $\begin{array}{l}\text { Males, Baltimore, } \\
\text { USA } \\
N=557\end{array}$ & $\begin{array}{l}\text { Single } \\
\text { question on } \\
\text { satisfaction } \\
\text { with } \\
\text { accomplishments }\end{array}$ & ts & $\begin{array}{l}5,3 \\
12,8\end{array}$ & $\begin{array}{l}+0.49 \\
+0.46\end{array}$ & $\begin{array}{l}\text { Costa et al., } \\
\text { 1981: } 81\end{array}$ \\
\hline
\end{tabular}


Appendix I (continued)

\begin{tabular}{|c|c|c|c|c|c|}
\hline Subjects & $\begin{array}{l}\text { Happiness } \\
\text { measure }\end{array}$ & $\begin{array}{l}\text { Happiness } \\
\text { variant }^{1}\end{array}$ & $\begin{array}{l}\text { Time } \\
\text { span } \\
\text { in } \\
\text { years }\end{array}$ & $\begin{array}{l}\text { Overtime- } \\
\text { correlation } \\
\text { (in r) }\end{array}$ & $\begin{array}{l}\text { Bibliografical } \\
\text { source }\end{array}$ \\
\hline $\begin{array}{l}\text { Mothers, USA. } \\
\text { Followed } 18 \\
\text { months after birth of } \\
\text { first child } \\
N=105\end{array}$ & $\begin{array}{l}\text { Single } \\
\text { question on } \\
\text { life- } \\
\text { satisfaction }\end{array}$ & $\mathrm{O}$ & $\begin{array}{l}0,6 \\
1,5\end{array}$ & $\begin{array}{l}+0.61 \\
+0.51\end{array}$ & Crnic, $1984^{2}$ \\
\hline $\begin{array}{l}\text { Elderly males, rural } \\
\text { USA } \\
N=1319\end{array}$ & $\begin{array}{l}\text { Single } \\
\text { question on } \\
\text { contentment } \\
\text { (how things } \\
\text { have worked } \\
\text { out for your) }\end{array}$ & $\mathrm{C}$ & 10 & +0.40 & $\begin{array}{l}\text { Dobson, } \\
\text { 1985: } 124^{3}\end{array}$ \\
\hline $\begin{array}{l}18+\text { aged, } \\
\text { Nebraska, } \\
\text { USA } \\
N=1188\end{array}$ & $\begin{array}{l}\text { Single } \\
\text { question on } \\
\text { happiness }\end{array}$ & $\mathrm{O}$ & $\begin{array}{l}2 \\
2 \\
4\end{array}$ & $\begin{array}{l}+0.41 \\
+0.38 \\
+0.34\end{array}$ & $\begin{array}{l}\text { Eels, } \\
\text { 1985: } 88\end{array}$ \\
\hline $\begin{array}{l}18-65 \\
\text { aged, Victo- } \\
\text { ria, Austria } \\
N=649\end{array}$ & $\begin{array}{l}\text { Single } \\
\text { question on } \\
\text { appreciation } \\
\text { of life, asked } \\
\text { twice each } \\
\text { interview } \\
\text { ( } 7 \text { step } \\
\text { Delighted- } \\
\text { Terrible } \\
\text { about life) }\end{array}$ & $\mathrm{O}$ & $\begin{array}{l}2 \\
4 \\
6\end{array}$ & $\begin{array}{l}+0.53 \\
+0.42\end{array}$ & $\begin{array}{l}\text { Heady, } \\
1989^{2}\end{array}$ \\
\hline
\end{tabular}


Appendix 1 (continued)

\begin{tabular}{|c|c|c|c|c|c|}
\hline Subjects & $\begin{array}{l}\text { Happiness } \\
\text { measure }\end{array}$ & $\begin{array}{l}\text { Happiness } \\
\text { variant }^{1}\end{array}$ & $\begin{array}{l}\text { Time } \\
\text { span } \\
\text { in } \\
\text { years }\end{array}$ & $\begin{array}{l}\text { Overtime- } \\
\text { correlation } \\
\text { (in r) }\end{array}$ & $\begin{array}{l}\text { Bibliografical } \\
\text { source }\end{array}$ \\
\hline \multirow[t]{2}{*}{$\begin{array}{l}\text { Voluntears, } \\
\text { Canada } \\
N=1000\end{array}$} & $\begin{array}{l}\text { Single } \\
\text { question on } \\
\text { appreciation } \\
\text { of life (10 step } \\
\text { Best-Worst } \\
\text { Possible life) }\end{array}$ & 0 & 7 & +0.17 & \multirow[t]{2}{*}{$\begin{array}{l}\text { Harley \& } \\
\text { Laverly, } \\
\text { 1991: 117 }\end{array}$} \\
\hline & $\begin{array}{l}\text { Single ques- } \\
\text { tion on life- } \\
\text { satisfaction }\end{array}$ & & 7 & +0.25 & \\
\hline \multirow{2}{*}{$\begin{array}{l}65-95 \text { aged, } \\
\text { Canada. } \\
\text { Living in } \\
\text { old-age } \\
\text { homes } \\
N=55\end{array}$} & $\begin{array}{l}10 \text { item Affect } \\
\text { Balance Scale }\end{array}$ & A & 0,9 & +0.27 & \multirow[t]{2}{*}{$\begin{array}{l}\text { Kozma \& } \\
\text { Stones, } \\
1980: 911\end{array}$} \\
\hline & $\begin{array}{l}2 \text { item index of } \\
\text { questions on } \\
\text { happiness 'at } \\
\text { this moment } \\
\text { of time' and } \\
\text { over the } \\
\text { past month' }\end{array}$ & 0 & 0,9 & +0.57 & \\
\hline \multirow{4}{*}{$\begin{array}{l}\text { 18+ aged, Germany. } \\
\text { Participants Socio- } \\
\text { Economic Panel } \\
N=7091\end{array}$} & \multirow{4}{*}{$\begin{array}{l}\text { Single } \\
\text { question on } \\
\text { life- } \\
\text { satisfaction } \\
\text { (10 step } \\
\text { satisfaction) }\end{array}$} & \multirow[t]{4}{*}{0} & $\begin{array}{l}1 \\
2\end{array}$ & +0.46 & \multirow[t]{4}{*}{$\begin{array}{l}\text { Landua } \\
1992^{2}\end{array}$} \\
\hline & & & $\begin{array}{l}4 \\
5\end{array}$ & +0.39 & \\
\hline & & & & +0.34 & \\
\hline & & & & +0.32 & \\
\hline \multirow{2}{*}{$\begin{array}{l}\text { Single males and } \\
\text { couples, Baltimore, } \\
\text { USA } \\
N=459\end{array}$} & $\begin{array}{l}10 \text { item Affect } \\
\text { Balance Scale }\end{array}$ & A & 2 & +0.51 & \multirow[t]{2}{*}{$\begin{array}{l}\text { McCrae \& } \\
\text { Costa, } \\
\text { 1991: } 229\end{array}$} \\
\hline & $\begin{array}{l}\text { Single ques- } \\
\text { tion on appre- } \\
\text { ciation of life } \\
\text { ( } 7 \text { step } \\
\text { Delighted- } \\
\text { Terrible Scale) }\end{array}$ & ) & 2 & +0.51 & \\
\hline
\end{tabular}


Appendix 1 (continued)

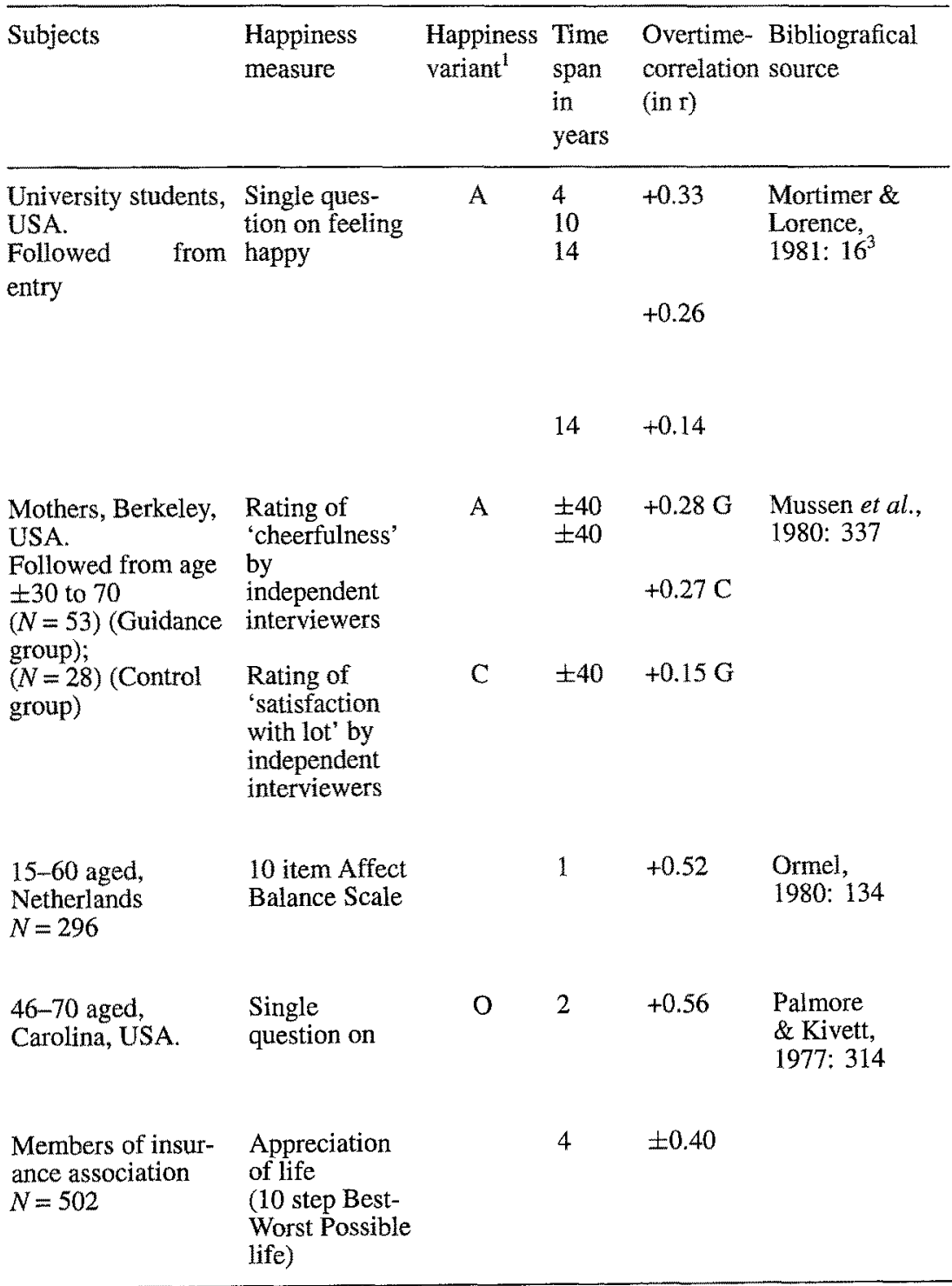


Appendix 1 (continued)

\begin{tabular}{|c|c|c|c|c|c|}
\hline Subjects & $\begin{array}{l}\text { Happiness } \\
\text { measure }\end{array}$ & $\begin{array}{l}\text { Happiness } \\
\text { variant }^{1}\end{array}$ & $\begin{array}{l}\text { Time } \\
\text { span } \\
\text { in } \\
\text { years }\end{array}$ & $\begin{array}{l}\text { Overtime- } \\
\text { correlation } \\
\text { (in } r \text { ) }\end{array}$ & $\begin{array}{l}\text { Bibliografical } \\
\text { source }\end{array}$ \\
\hline $\begin{array}{l}\text { Babies, Berkeley, } \\
\text { USA. } \\
\text { Followed from birth } \\
\text { to age } 3 \text {. } \\
\text { Males }(N=27) \\
\text { Females }(N=27)\end{array}$ & $\begin{array}{l}\text { Time- } \\
\text { sampling of } \\
\text { cheerful } \\
\text { utterances } \\
\text { Ratings were } \\
\text { made at regu- } \\
\text { lar visits } \\
\text { at home and in } \\
\text { clinic. } \\
\text { Ratings } \\
\text { were made at } \\
\text { month: } 10 \text {, } \\
11,12,13,14 \text {, } \\
15,18,21,24 \text {, } \\
27,30 \\
\text { and } 36\end{array}$ & A & 0,4 & $\begin{array}{l}+0.61 \mathrm{M} \\
+0.51 \mathrm{~F} \\
+5.0 \mathrm{M} \\
+0.48 \mathrm{~F}\end{array}$ & $\begin{array}{l}\text { Schaefer } \\
\text { \& Baily, } \\
\text { 1963: } 29\end{array}$ \\
\hline $\begin{array}{l}\text { Babies, Berkeley, } \\
\text { USA. } \\
\text { Followed from birth } \\
\text { into adolescence } \\
\text { (above sample, girls } \\
\text { only) } \\
(N=19)\end{array}$ & $\begin{array}{l}\text { Time- } \\
\text { sampling of } \\
\text { baby } \\
\text { cheerfulness } \\
\text { (above } \\
\text { and extensive } \\
\text { interviews } \\
\text { on the basis of } \\
\text { which a } \\
\text { rating of } \\
\text { adolescent } \\
\text { 'cheerfulness' } \\
\text { was made }\end{array}$ & $\mathrm{A}$ & \pm 14 & $-0.11 \mathrm{~F}$ & $\begin{array}{l}\text { Schaefer } \\
\text { \& Baily, } \\
\text { 1963: } 105\end{array}$ \\
\hline $\begin{array}{l}\text { Basic school pupils, } \\
\text { USA. } \\
\text { Followed from } \\
\text { grade } 6 \text { to } 10 \\
(N=310)\end{array}$ & $\begin{array}{l}4 \text { item } \\
\text { Rosenberg/Sim } \\
\text { Depression } \\
\text { Scale }\end{array}$ & mons & $\begin{array}{l}1 \\
4\end{array}$ & $\begin{array}{l}+0.42 \\
+0.25\end{array}$ & $\begin{array}{l}\text { Simmons et al., } \\
1987: 107\end{array}$ \\
\hline
\end{tabular}


Appendix 1 (continued)

\begin{tabular}{|c|c|c|c|c|c|}
\hline Subjects & $\begin{array}{l}\text { Happiness } \\
\text { measure }\end{array}$ & $\begin{array}{l}\text { Happiness } \\
\text { variant }^{1}\end{array}$ & $\begin{array}{l}\text { Time } \\
\text { span } \\
\text { in } \\
\text { years }\end{array}$ & $\begin{array}{l}\text { Overtime- } \\
\text { correlation } \\
\text { (in r) }\end{array}$ & $\begin{array}{l}\text { Bibliografical } \\
\text { source }\end{array}$ \\
\hline $\begin{array}{l}\text { Grandparents and } \\
\text { grandchildren, USA } \\
(N=1159)\end{array}$ & $\begin{array}{l}10 \text { item Affect } \\
\text { Balance Scale }\end{array}$ & A & 14 & +0.32 & $\begin{array}{l}\text { Stacey \& Gatz, } \\
\text { 1991: } 77\end{array}$ \\
\hline $\begin{array}{l}\text { Highschoolseniors } \\
\text { USA. } \\
\text { Folowed into } \\
\text { adulthood. } \\
\text { Males }(N=32) \text {; } \\
\text { Females }(N=40) \text {. } \\
\text { Largely same sub- } \\
\text { jects as in Block } \\
\text { (above) }\end{array}$ & $\begin{array}{l}\text { Rating } \\
\text { of cheerfulness } \\
\text { (vs gloomy) } \\
\text { on the basis of } \\
\text { extensive } \\
\text { interview } \\
\text { protocols }\end{array}$ & A & $\begin{array}{l}19 \\
19\end{array}$ & $\begin{array}{l}+0.26 \mathrm{M} \\
+0.20 \mathrm{~F}\end{array}$ & $\begin{array}{l}\text { Tuddenham, } \\
\text { 1959: } 16\end{array}$ \\
\hline $\begin{array}{l}\text { Highschool seniors, } \\
\text { USA } \\
\text { Followed into } \\
\text { adulthood } \\
\text { Males: } N=51 \\
\text { Females: } N=41\end{array}$ & $\begin{array}{l}\text { Single ques- } \\
\text { tion of enjoy- } \\
\text { ment and } \\
\text { disapointments } \\
\text { in life } \\
\text { Single ques- } \\
\text { tion on realisa- } \\
\text { tion of wants }\end{array}$ & $\mathrm{C}$ & $\begin{array}{l}15 \\
15 \\
15 \\
15\end{array}$ & $\begin{array}{l}+0.10 \mathrm{M} \\
+0.19 \mathrm{~F} \\
+0.23 \mathrm{M} \\
+0.08 \mathrm{~F}\end{array}$ & $\begin{array}{l}\text { Tuddenham, } \\
\text { 1962: } 666\end{array}$ \\
\hline $\begin{array}{l}30-50 \text { aged, } \\
\text { Netherlands. } \\
\text { Employed and } \\
\text { unemployed } \\
(N=337)\end{array}$ & $\begin{array}{l}10 \text { item Affect } \\
\text { Balance Scale }\end{array}$ & A & 1 & +0.48 & $\begin{array}{l}\text { Verkley \& Stolk, } \\
\text { 1989: } 91\end{array}$ \\
\hline $\begin{array}{l}65+\text { aged, patients, } \\
\text { USA. } \\
\text { Geriatric and gen- } \\
\text { eral medical } \\
\text { clinic } \\
(N=205)\end{array}$ & $\begin{array}{l}10 \text { item Affect } \\
\text { Balance Scale }\end{array}$ & A & 1,5 & +0.32 & $\begin{array}{l}\text { Yeo et al., } \\
\text { 1987: } 256^{3}\end{array}$ \\
\hline
\end{tabular}

${ }^{1} \mathrm{O}=$ Overall happiness, $\mathrm{A}=$ Affect, level $\mathrm{C}=$ Contentment

${ }^{2}$ Overtime correlations provided by author

${ }^{3}$ Overtime correlations computed from data in report 


\section{APPENDIX 2}

\section{Country-characteristics (used in figure 4)}

Material comfort is measured by the real income per head. 'Real' income means that non-marked goods and services are taken into account as well, and that purchasing power differences are controlled for. Data was drawn from Summers and Heston (1988: 125). Next to income as such, I also considered income security. I expect this security to be higher in the so-called welfare states which guarantee their citizens a minimum material level of living. By lack of comparable measures for social security as such, in the countries at hand, I took proportions of government expenditures (minus defence) in the gross national product as a proxi. Data were drawn from IMF-statistics (IMF 1987) and Japanese government statistics (Min. of Finance Japan 1986).

Social equality was measured by inequality between the sexes. Emancipation of women was measured by Estes' $(1984: 171 ; 184 / 5)$ Index of Women Status, which involves educational participation of women and womens' suffrage. Income equality was not used in this analysis by lack of comparable data.

Freedom was measured by freedom of press. Data on that matter from the early 1970's was found in Kurian (1979: 362). I also considered the political democracy in the country. For that purpose I took Estes' Index of Political Paticipation (Estes 1984: 175-187). This index involves independance of the country, presence and functioning of a parliamentary system and limitation of influence of the military.

Access to knowledge was measured by scope of education in the country and attendance to mass media. As an indicator of educational performance I took Estes' Education Index (Estes 1984: 169; 183/4). This index involves school enrolment, expenses on education and literacy. As an indicator of access to information from mass media we took the summed scores of daily newspaper circulation and the number of radio's as found in Kurian (1979: 347-359).

\section{APPENDIX 3}

Data about migrant happiness used in exhibit 10

1. Victoria Immigrant Survey, 1981, Secondary analysis, 1-9 Terrible-Delighted scale transformed lineary to $0-10$.

2. Australian National Science Survey, 1984, Secondar analysis, 1-10 DissatisfiedSatisfied scale transformed linearly to $0-10$.

3. German Survey among foreign workers (Ausländerumfrage), 1982. Data reported in Zapf \& Bracht1, 1984: 294, 0-10 Utmost dissatified-Utmost satisfied scale. 
4. German Socio-Economical Panel, first wave, 1984, Secondary analysis, 0-10 Utmost dissatisfied-Utmost satisfied scale.

5. German Welfare Survey (Wohlfahrtssurvey) 1980. Data reported in Zapf \& Brachtl 1984: 294.

6. Eurobarometer 19, 1983. Data reported in Inglehart 1985: 12, 0-10 very dissatisfied-very satisfied scale.

7. European Value Study 1981, Secondary analysis, 1-10 dissatisfied-satisfied scale transformed linearly to 0-10.

8. Estimate on the basis of a cross-national study among university students in which Turkish students scored very low (4.2 on a 1-7 Terrible Delighted Scale) and lower than students in Greece, Spain and Yugoslavia (Michalos 1991: 83).

9. Estimate on the basis of:

a. National sample in 1962 which observed a score 5.0 on a $0-10$ Worst-Best Possible Life scale (Cantril, 1965: 258).

b. Cross-national study among $15-40$ aged in 1967 in which Slovenia scored 5.06 on a $1-9$ Worst-Best Possible Life scale (5.1 on 0-10 scale).

\section{NOTES}

1 An earlier version of this paper was presented at the 12 th World Conference of the International Sociological Association in Madrid, 1990.

2 This study was supported by grant nr. 560-270-023 of the Nederlandse organisatie voor Wetenschappelijk Onderzoek (NWO).

${ }^{3}$ Part of the analyses were performed by Piet Ouweneel. I thank Joop Ehrhardt for his valuable comments.

4 The analyses reported in this paragraph were made during my stay at the Wissenschaftzentrum für Sozialwissenschaften Berlin, November 1992.

\section{REFERENCES}

Adams, R. G.: 1988, "Which comes first: poor psychological well-being or decreased friendship activity?' Activities, Adaptation and Aging 12, pp. 27-41.

Andrews, F. M. and Withey, S. B.: 1976, Social indicators of Well-Being (Plenum Press, New York).

Bahr, H. M. and Harvey, C. D.: 1980, 'Correlates of Morale among the newly widowed', Journal of Psychology 110, pp. 219-233.

Block, J.: 1971, Lives Through Time (Bancroft, Berkely, California), pp. 293-307. 
Brachtel, W. and Zapf, W.: 1984, 'Stabilität und Wandel individueller Wohlfahrt: Panel Ergebnisse', in: Glatzer, W. and Zapf, W. (eds), Lebensqualität in der Bundesrepublik' Campus (Frankfurt/Main), pp. 323-342.

Bradburn, N. M.: 1969, The Structure of Psychological Well-Being (Aldine, Chicago).

Brickman, P. Coates, D. and Janoff-Bullman, R.: 1978, 'Lottery winners and accident victims: Is happiness relative?', Journal of Personality and Social Psychology 36, pp. 917-927.

Brim, O. G. jr.: 1970, 'Personalty development as role-learning', in: Scott, W. R. (ed), Social Process and Social Structure (Holt, New York), pp. 158-169.

Buchanan, W. and Cantril, H.: 1953, How Nations See Each Other. A Study in Public Opinion (University of Illinois Press, Urbana, USA).

Buss, A. H. and Plomin, R.: 1975, A Temperament Theory of Personality Development (Wiley, New York).

Cameron, P. et al:: 1973, 'The life satisfaction of non-normal persons', Journal of Consulting and Clinical Psychology 41, pp. 207-214.

Cantril, H.: 1965, The Pattern of Human Concern (Rutgers University Press, New Brunswick, NJ).

Chamberlain, K. and Zika, S.: 1972, 'Stability and Change, in subjective well-being over short time periods', Social Indicator Research 26, pp, 101-117.

Chaplin, W. T. John O. P. and Goldberg L. R, 1988, 'Conceptions of states and traits', Journal of Personality and Social Psychology 54, pp. 541-557.

Chin Hon Foei, S.: 1989, 'Life-satisfaction in the EC countries 1975-1984', in: Veenhoven, R. (ed), Did the Crisis Really Hurt? Effects of the 1980-1982 Economic Recession on Satisfaction, Mental Health and Mortality (Universitaire Pers Rotterdam, Den Haag).

Chiriboga, D. A.: 1982, 'Concistency in adult functioning: the infuence of social stress', Aging and Society 2, pp. 7-29.

Chiriboga, D. A.: 1984, 'Social stressors as antecedents of change', Journal of Gerontology 39 , pp. $468-477$.

Chiriboga, D. A.: 1989, 'Stress and loss in middle age', in: Kaiish, R. E. (ed), Midlife Loss: Coping Strategies (Sage, London).

Costa, P. T. et al:: 1987, 'Longitudinal analysis of psychological well-being in national sample: stability of mean levels', Journal of Gerontology 42 , pp. $50-55$.

Costa, P. T., McCrae, R. R. and Norris, A. H.: 1981, 'Personal Adjustment to aging: longitudinal prediction from neuroticism and extraversion', Journal of Gerontology 36, pp. 78-85.

Costa, P. T. and McCrae, R. R.; 1984, 'Concurrent validation after 20 years: the implications of personality stability for its assessment', in: Butcher, J. N. and Spielberger, C. D. (eds), Advances in Personality Assessment (Erlbaum, Hillsdale, New York), pp. $31-54$.

Costa, P. T. and McCrae, R. R.: 1988, 'Personality in adulthood', Journal of Personality and Social Psychology 54, pp. 853-863. 
Costa, P. T., McCrae, R. R. and Zonderman, A. B.: 1987, 'Environmental and dispositional influences on well-being longitudinal follow-up of an American national sample', British Journal of Psychology 78, pp. 299-306.

Dam van, M. Puyenbroek van, R. and Verschuren, P.: 1989, 'De centrum-periferie theorie, Intra - versus internationale determinanten van inkomensongelijkheid', Mens en Maatschappij 2, pp. 5-21.

Davis. J. A.: 1984, 'New money, an old man, lady and two's company: Subjective welfare in the NORC general Social Surveys 1972-1982', Social Indicators Reseach 15, pp. 319-356.

DeFrain, J. D. and Ernst, L.: 1978, 'The psychological effect of sudden infant death syndrome on surviving family members', Journal of Family Practice 6, pp. 985-989.

Diener, E., Larsen, R. J. and Emmons, R. A.: 1984, 'Bias in mood recall in happy and unhappy persons', Paper (American Psychological Association, Toronto).

Dobson, C.: 1985, 'Attitudes and Perceptions', in: Powers, E. A., Goudy, W. J. and Keith, P. M. (eds), Late Life Transitions (Kluwer Academic, Dordrecht), pp. 123-136.

Easterlin, R. A.: 1974, 'Does economic growth improve the human lot? Some empirical evidence', in: David P. A. and Melvin, W. R. (eds), Nations and Households in Economic Growth (Stanford University Press, Palo Alto, California, USA).

Eels, L. W.: 1985, The Effect of Role Change on Psysical Health, Mental Health and General Life-Satisfaction: A Panel Analysis [Dissertation] (University of Nebraska, Michigan).

Estes, R. J.: 1984, The Social Progress of Nations (Praeger, New York).

Feather, N. T. and O'Brien, G. E.: 1986, 'A longitudinal study of the effects of employment on schoolleavers', Journal of Occupational Psychology 59, pp. 121-144.

Friedrich, W. N. and Friedrich, W. L.: 1981, 'Psychological assets of parents of handicapped and non-handicapped children', American Journal of Mental Deficiency 85, pp. 551-553.

Gallup, G. H. and Kettering, C. F.: 1976, Human Needs and Satisfactions a Global Survey [Research Report] (C.F. Kettering Foundation and Gallup International Research Institutes).

George, V. and Lawson, R.: 1980, Poverty and Inequality in Common Market Countries (London: Routlegde and Kegan Paul, London).

Gergen, K. J.: 1972, 'Multiple identity: the happy healthy human being wears many masks', Psychology Today.

Glenn, N. D.: 1975, 'The contribution of marriage to the psychological well-being of males and females', Journal of Marriage and the Family 37, pp. 594-601.

Halman, L.: 1991, Waarden in de Westerse Wereld (Tilburg University Press, Tilburg).

Halman, L., Heunks, F., Moor, R. de and Zanders, H.: 1987, Traditie, Secularisatie en Individualisering (Tilburg University Press, Tilburg).

Harding, S.: 1985, 'Values and the nature of psychological well-being', in: Abrams, M. Gerard, D. and Timms, N. (eds), Values and Social Change in Britain (McMillan, London). 
Harley, J. and Lavery, J. J.: 1991, 'The stability and sensitivity of subjective well-being measures'. Social Indicators Research 24, pp. 113-122.

Heady, B. and Veenhoven, R.: 1989, 'Does happiness induce a rosy outlook?', in: Veenhoven, R. (ed), How Harmful Is Happiness? (Universitaire Pers Rotterdam, The Netherlands).

Heady, B. and Wearing, A.: 1989, 'Personality: Life-events and subjective well-being: towards a dynamic equilibrium model', Journal of Personality and Social Psychology 57 , pp. 731-734.

Heady B. and Wearing, A.: 1992, Understanding Happiness: A Theory of Subjective Well-Being (Longman Cheshire, Sydney, Australia).

Hornstra, R. K. and Klassen, D.: 1977, 'The course of depression', Comprehensive Psychiatry 18, pp. 119-125.

IMF: 1987, Government Finance Statistics Yearbook, vol. XI (Washington),

Inglehart, R.: 1977, The Silent Revolution (Princeton University Press, New Yersey, USA).

Inglehart, R.: 1990, Culture Shift in Advanced Industrial Society (Ptinceton University Press, New Yersey, USA).

Inkeles, A: 1960, 'Industrial man: the relation of status of experience perception, and value', American Journal of Sociology 66, pp. 1-31.

Inkeles, A.: 1990/91, 'National character revisited', The Tocqueville Review 12, pp. 83117.

Kirchler, E.: 1985, 'Jobloss and mood', Journal of Economic Psychology 6, pp. 9-25.

Kozma, A. et al. : 1990, 'Long- and short-term affective states in happiness', Social Indicators Research 22, pp. 119-138.

Kuhlen, R. G.: 1948, 'Age trends in adjustment during the adult years as reflected in happiness ratings', American Psychologist 3, p. 307.

Kurian, G. T.: 1979, The Book of World Rankings (McMillam Reference Books, London).

Landua, D.: 1992, 'Satisfaction changes', Social Indicators Research 26, pp. 221-241.

Lieberman, L. R.: 1970, 'Life satisfaction in the young and the old', Psychological Reports 27, pp. 75-79.

Matlin, M. W. and Gawron, V. J.: 1979, 'Individual differences in Polyannaisn', Journal of Personality Assesment 43, pp. 411-412.

McCrae, R. R.: 1984, 'Personality as a lifelong determinant of well-being', in: Malatesta, C. Z. and Izard, C. E. (eds), Emotioning Adult Development (Sage, Beverly Hills, California), pp. 143-153.

McCrae, R. R. and Costa, P. T.: 1990, 'Adding Liebe und Arbeit: the full five-factor model and well-being', Personality and Social Psychology Bulletin 17, pp. 227-232.

McKinley Runyan, W.: 1979, 'Perceived determinants of highs and lows in lifesatisfaction', Developmental Psychology 15, pp. 331-333.

McNeil, J. K. Stones, M. J. and Kozma, A.: 1986, 'Subjective well-being in late 
life; issues concerning measurement and prediction', Social Indicators Research 18, pp. $35-70$.

Meneghan, E. G. and Lieberman, M. A.: 1986, 'Changes in depression following divorces: a panel study', Journal of Marriage and the Family 48, pp. 319-328.

Michalos, A.: 1991, 'Global Report on Student Well-Being', Vol. I, 'Life satisfaction and Happiness' (Springer Verlag, New York).

Mohr, H. M.: 1986, Subjektives Wohlbefinden (Subjective well-being) [Paper] Presented at the Conference of the German Sociological Association, Hamburg.

Moller, V.: 1988, 'The relevance of personal domain satisfaction', South-Africa Tydskrif Sielkunde (S-Afr. Journal of Psychiatry), p. 74.

Mortimer, J. T. and Lorence, J.: 1981, 'Self-concept Stability and change from late adolescence to early adulthood', Research in Community and Mental Health 2, pp. 542.

Mussen, P., Honzik and Eichorn: 1982, 'Early adult antecedents of life satisfaction at age 70', Journal of Gerontology 37, pp. 316-322.

Mussen, P. Eichhorn, D. H. Honzik, M. P. Biebe, S. L. and Meredith, W. 1980, 'Continuity and change in women's characteristics over four decades', International Journal of Behavioral Development 3, pp. 331-347.

Moum, T: 1988 , Yeah saying and mood-of-the-day effects in self reported quality of life, Social Indicators Research 20, pp. 117-139.

Naroll, R.: 1982, The Moral Order (London, Sage).

Neugarten, B. L. Hovinghurst, R. J. and Tobin, S. S.: 1961, 'The measurement of life-satisfaction", Journal of Gerontology 16, pp. 134-143.

Ormel, J.: 1980, Moeite met Leven of een Moeilijk Leven (Difficulty with Living or a Difficult Life) (Konstapel, Groningen, Holland).

Ostroot, N. and Snyder, W.: 1985, 'Measuring cultural bias in a cross-national study', Social Indicators Research 17, pp. 243-251.

Ouweneel, P. and Veenhoven, R.: 1991, 'Cross national differences in happiness: Cultural bias or societal quality', in: Bleichrodt, N. and Drenth, P. J. (eds), Contemporary Issues in Cross Cultural Psychology (Swets and Zeitlinger, Amsterdam/Lisse, The Netherlands), pp. 168-184.

Palmore, E. and Kivett, V.: 1977, 'Change in life-satisfaction: a longitudinal study of persons aged 46-70', Journal of Gerontology 32, pp. 311-316.

Prime Minister Office: 1987, Public Opinion Survey on the Life of the Nation (Foreign Press Center, Tokyo, Japan).

Rosenberg, M: 1962, 'The dissonant religious context and emotional disturbance', American Journal of Sociology 68, pp. 1-10.

Schaefer, E. S. and Bayley, N.: 1963, 'Maternal behavior, child behavior, and their intercorrelations', Monographs of the Society for Research in Child Development 28(3).

Schulz, B. and Decker, S.: 1985, 'Long term adjustement to physical disability', Journal of Personality and Social Psychology 48, pp. 1162-72. 
Simmons, R. G., Klein, S. D. and Simmons, R. C.: 1977, Gift of Life (Wiley, London).

Simmons, R. G. and Blyth, D. A.: 1987, Moving into Adolescence (Aldine de Gruyter, New York).

Stacey, A. and Gatz, M.: 1991, 'Cross-sectional agedifferences and longitudinal change on the Bradburn Affect Balance Scale', Joumal of Gerontology 46, pp. 76-78.

Stones, M. J. and Kozma, A.: 1989, 'Happiness and activities in late life: a propensity formulation', Canadian Psychology 30, pp. 526, 537.

Stones, M. J., Kozma, A. Hannak, I. E. and Mc Kim, W. A.: 1991, 'The correlation coefficient and models of Subjective Well-Being', Social Indicators Research 24, pp. $317-327$.

Summers, R. and Heston, A.: 1988, 'A new set of international comparisons of real product and price level estimates for 130 countries, 1950-1985', National Income and Wealth 34 , pp. $1-25$.

Tellegen, A. et al.: 1988, 'Personality similarity in twins reared apart and together', Journal of Personality and Social Psychology 54, pp. 1031-1037.

Tuddenham, R. D.: 1959, 'Constancy of personality ratings over two decades', Genetic Psychology Monographs 60, pp. 3-29.

Tuddenham, R. D.: 1962 , 'Constancy of personal morale over a fifteen year interval': Child Devellopment 33, pp. 663-673.

United Nations: 1986, 1983/84 Statistical Yearbook (United Nations, New York).

Veenhoven, R.: 1984, Conditions of Happiness (Reidel, Dordrecht, Holland).

Veenhoven, R.: 1987, 'Cultural Bias in ratings of perceived life quality: a comment on Ostroot and Snyder", Social Indicators Research 19, pp. 329-334.

Veenhoven, R.: 1988, 'The utility of happiness', Social Indicators Research 20, pp. 33354.

Veenhoven, R. (ed.): 1989 , 'Did the crisis really hurt? Effects of the 1980-82 economic recession on satisfaction, mental health and mortality', (Universitaire Pers Rotterdam, Rotterdam, )

Veenhoven, R. (ed.): 1989, How Harmfull is Happiness?: Consequences of Enjoying Life or Not (Universitaire Pers Rotterdam, Rotterdam).

Veenhoven, R.: 1991, 'Is happiness relative?', Social Indicators Research 24, pp. 1-34.

Veenhoven, R.: 1991, 'Questions on happiness, classical topics, modern answers, bind spots', in: Strack, F., Argyle, M. and Schwarz, N. (eds), Subjective Well-Being: In Interdisciplinary Perspective (London), pp. 7-26.

Veenhoven, R.: 1992, World Database of Happiness. Ongoing catalogue of research on subjective appreciation of life. Catalogue of correlates. Printout September 1992 (Erasmus University, Rotterdam, The Netherlands). Electronically published on ftp.eurnl (pub\database.happiness \correlat).

Veenhoven, R.: 1993, Happiness in Nations (RISBO, Rotterdam). Electronically published on ftp.eur.nl (pub\database.happiness \nations).

Verkley, H. and Stolk, J.: 1989, 'Does happiness lead into idleness?', in: Veenhoven (ed), How Harmful is Happiness (Univ. Pers Rotterdam, Holland), pp. 79-93. 
Verkuyten, M.: 1986, 'Opgroeien in den vreemde', Gezondheid en Samenleving 7, pp. 1-6.

Verkuyten, M. and Veenhoven, R.: 1988, 'Welbevinden van kinderen na echtscheding: een onderzoek onder adolescenten' ('Wellbeing of children after divorce: a study of adolescents'), Tijdschrift voor Sociale Gezondheidszorg 66, pp. 128-133.

Waltz, M.: 1986, 'A longitudinal study on environment and dispositional determinants of life quality: social support and coping with physical illness', Social Indicators Research 18, pp. 71-93.

Wierzbicki, M: 1986, 'Similarity of monozygotic and dizigotic twins in level and lability of subclinically depresses mood', Journal of Clinical Psychology 42, 577 585.

Yardley, J. K. and Rice, R. W.: 1991, 'The relationship between mood and subjective well-being', Social Indicators Research 24, pp, 101-111.

Yeo, G. Ingram, L. Skunnic, J. and Crapo, L.: 1987, 'Effects of a geriatric clinic on functional health and well-being of elders', Journal of Gerontology 42, pp. 252-258.

Young, P. T.: 1937, 'Is cheerfullness-depression a general temperamental trait?: A study of moods in college students', Psychological Review 44, pp. 313-319.

Zapf, W. and Brachtel, W.: 1984, 'Gastarbeiter und Deutsche Bevolkerung', in: Glatzer, W. and Zapf, W. (eds), Lebensqualität in der Bundesrepublik (Campus, Frankfurt/Main), pp. 286-306.

Erasmus University of Rotterdam,

POB 1738

3000 DR Rotterdam, The Netherlands 